\title{
A FILOSOFIA ESPÍRITA. O DIREITO NATURAL. O DIREITO JUSTO
}

\author{
THE PHILOSOPHY OF THE SPIRITISM. NATURAL RIGHTS. THE FAIR LAW
}

Antonio Augusto Machado de Campos Neto ${ }^{1}$

\begin{abstract}
Resumo:
A Filosofia Espírita é a Episteme, a Ciência Metodológica, isto é, o caminho que envolve a razão e a fé em entrelaçamento de idéias claras e distintas, nos mesmos moldes de René Descartes, em que a verdade emerge na expressão legítima da sua essencialidade transparente (o chamado "manto diáfano"), sem fantasia, porém da mais pura e verdadeira realidade. A Filosofia Espírita tem, ainda, estreitas ligações com a tradição filosófica do Realismo Metafísico que parte de Parmênides, tomando o Ser, com o qual identifica o Espírito junto às suas respectivas qualidades; todavia, cada Ser ou Espírito com sua unicidade, eternidade, infinitude e imutabilidade na intimidade da própria essência criada. O Direito Natural e o Direito Justo complementam este trabalho, uma vez implícitos à essência da Filosofia e seus temas.
\end{abstract}

Palavras-chaves: Filosofia Espírita. Espiritismo. Espírita. Espiritualismo. Cristianismo. Ciência Espírita. Direito Natural. Direito Justo.

\begin{abstract}
:
The Spiritism Philosophy is an Epistemology, a Methodological Science, the way that contains the reason and the faith in an intertwined of clear and distinct ideas, like thought by René Descartes, in which the truth emerges in the legitimal expression of its clear essentiality (the so-called "ethereal mantle"), without fantasy, but from the purest and truest reality. The Spiritism Philosophy has close links with the philosophical tradition, the Metaphysical Realism, what emanates form Parmenides - taking the Being, identificated as the spirit; besides, each Being or Spirit with its unity, eternity, infinity and immortality inside of its own created essence. The Natural Law and the Fair Law complement this work, for they are implied in the essence of the Philosophy.
\end{abstract}

Keywords: Philosophy of Spiritism. Spiritism. Spirit. Spiritualism. Cristianism. Spirit Science. Natural Law. Fair Law.

Não importa se a estação do ano muda, se o século vira e se o milênio é outro, se a idade aumenta; conserve a vontade de viver, não se chega à parte alguma sem ela.

(Fernando Pessoa)

1 Bacharel em Direito pela Faculdade de Direito da Universidade de São Paulo. Jornalista e Editor da Revista da Faculdade de Direito da Universidade de São Paulo. aaneto@usp.br. 
"Embora ninguém possa voltar atrás e fazer um novo começo, qualquer um pode começar agora e fazer um novo fim".

\section{(Chico Xavier)}

\section{Introdução}

\subsection{Os fenômenos de Hydesville. A Doutrina Espírita}

Em 1848, Hydesville era uma pequena aldeia dos EUA quando, em março daquele ano, aconteceram os primeiros fenômenos mediúnicos dos tempos modernos, representando, o fato, o prelúdio do advento da Doutrina Espírita consumado pela codificação kardeciana.

Dada a pequenez da cidade, as casas eram de madeira e em uma delas vivia a Família de John Fox, composta pelos pais e vários filhos. Dentre eles, Margareth, de 14 anos, e Kate, de 11 anos. A Família Fox veio morar naquele local em 11 de dezembro de 1847. Após a mudança, os ocupantes passaram a ouvir ruídos nas paredes, arranhões nos móveis e assoalhos, vibradas no forro dos compartimentos, vidros das janelas estilhaçados, preocupando imensamente aquela família. As madeiras, acessórios de construção preferidos da época, intensificavam os ruídos alarmantes.

As duas meninas menores foram imediatamente afastadas da casa e uma delas, Margareth, levada para a residência de David Fox, tio delas. A outra menina, Kate, à da tia, irmã do pai, a Sra. Leah Fish - de sobrenome diferente por ser casada -, em Rochester. Tudo indicava que os fenômenos estivessem ligados às duas meninas.

Alguns meses elas retornam à casa, quando os fenômenos continuaram. Nesse espaço de tempo, Kate, a menor, em 31 de março de 1848, descobre e cria um método de se comunicar com entidades espirituais; no caso, uma única entidade que produzia aqueles fenômenos.

O método foi o de bater palmas; por exemplo: Kate dizia: "Senhor faça o que eu faço", batendo palmas repetidamente. As palmas se repetiam com a mesma intensidade. Havia se estabelecido um método de comunicação com o mundo espiritual, sui generis, em alfabeto totalmente convencional, por meio de pancadas.

E por intermédio desse sistema rudimentar, descobre-se que o Espírito comunicante era um vendedor ambulante chamado Charles Rosna, que procurava revelar a sua presença e entrar em contato com aquelas pessoas. Complementa-se que havia sido assassinado na casa de Hydesville, na qual a Família Fox fora residir. O motivo do 
homicídio, dinheiro, cerca de 500 dólares, que ele possuía guardado nesta casa, aonde morava. E que o fato acontecera há mais de cinco anos, anterior ao relato codificado. $\mathrm{O}$ enredo fora apurado por meio do método de comunicação supracitado.

Na seqüência, na noite de primeiro de abril de 1848 - mediante informações colhidas pela Família Fox -, iniciaram-se escavações no solo da casa; todavia, somente no dia 22 de novembro de 1904, com a queda de uma parede, verificou-se a existência de um esqueleto e, junto, um baú que pertencera ao mascate.

Com o passar dos tempos, considerou-se que Margareth e Kate eram médiuns; que inconsciente e involuntariamente agiam, mediante intervenção na produção dos fenômenos. Mais: que a elas estava reservada a missão de cooperar no importante movimento de idéias, o qual, por sua vez, de semelhante forma, não tardaria a atrair a atenção do mundo.

Uma série de investigações aconteceu com a formação de comissões investigativas, as quais unanimemente confirmaram as pesquisas. Cumpre salientar que as meninas sofreram nas mãos dos investigadores e seus auxiliares. No decurso delas, senhoras - membros das comissões -, exigiam que fossem despidas, submetendo-as a investigações brutais e aflitivas.

Dentre as cenas passadas, os vestidos das meninas foram amarrados, apertados aos corpos e elas expostas em vidros, aos moldes de aquários.

A Comissão, em parecer, referiu-se que:

quando elas se achavam de pé sobre as almofadas, com lenços amarrados à borda dos seus vestidos, amarradas pelas cadeiras, todos nós ouvimos as batidas distintas nas paredes, no assoalho e em outros objetos.

Por fim, a Comissão declarou, enfaticamente, que às suas perguntas, das quais algumas realizadas mentalmente, tinham sido respondidas corretamente.

As perseguições sofridas por Margareth e Kate Fox foram inenarráveis.

Um jornal denominado Rochester Democrat havia tirado uma edição com a manchete "Exposição Completa da Mistificação das Batidas". O resultado das pesquisas obrigou o seu Editor a sustar a distribuição do periódico.

Em 1850, foram recebidas em salas separadas, em Rochester, duas mensagens simultâneas do Espírito de Benjamin Franklin, cujo teor era o seguinte:

Haverá grandes mudanças no século XIX. Coisas que, atualmente, parecem obscuras e misteriosas, para vós, tornar-se-ão claras aos vossos olhos. Os mistérios vão ser revelados. O mundo será esclarecido. 


\subsection{As mesas-girantes}

As mesas-girantes são um fenômeno surgido em França, nas décadas de 1850-1860, constituindo suas manifestações em outros países como EUA e Suécia. Todavia, em Paris, o fenômeno toma vulto e torna-se objeto de atenções diversas.

Inicialmente, surgem móveis - mesas, principalmente, e cadeiras - que se movem repentinamente, sem causa alguma aparente a lhes impulsionar ou sustentar os movimentos. Esses fenômenos, em larga escala, passam a ser observados nos salões parisienses, sendo que, em curto espaço de tempo, descobre-se a possibilidade de se entravar comunicações inteligentes com tais objetos.

Semelhantes àqueles de Hydesville, iniciam-se indagações e respostas, por meio de batidas ou de movimentos, sendo convencionados números, letras e respostas, seguindo batidas e direção do movimento.

Esses fenômenos atraem fortemente a atenção mundial, tendo sido as mesasgirantes motivo das mais variadas posições ao seu respeito; por exemplo, charlatanismo para uns, efeitos de causas física ou psíquica para outros, intervenções dos mortos para tantos e atuação demoníaca para incrédulos.

Com o passar dos tempos, as mesas-que-giravam e que se comunicavam tornam-se popularizadas e asseguram prestações das mais diversas funções para o público que as presenciava, tais como objetos de diversão, conselheiras de eventuais problemas, adivinhadoras de sorte e de futuro, acompanhamentos de números musicais, serviçais em trabalhos dos mais variados tipos e até mesmo, conforme se relata em caso de jornais parisienses da época, testemunha de crime ocorrido em suas presenças.

Em dezembro, de 1854, o professor Léon-Hippolyte Denizard Rivail, ainda sem a alcunha de Allan Kardec, toma contato com o fenômeno das mesas-girantes, por meio do Sr. Fortier, em Paris. Freqüenta - sem acreditar previamente, todavia dedicandose em descobrir as causas dos fenômenos - as sessões em casa da Sra. Plainemaison e nas dos Senhores Baudin e Roustan, onde tomava parte, como médium, a Srta. Japhet, posteriormente aclamada uma das mulheres mais sensitivas do Espiritismo.

E assim, com esses e outros casos de fenômenos desta natureza, Denizard Rivail iniciou estudos científicos e contatos com médiuns e Espíritos, que resultaram em trabalho de codificação e estudos integrantes da Doutrina Espírita.

Ressalta-se que a Doutrina Espírita "é a única grande matriz religiosa surgida na modernidade, segundo a égide da razão do conhecimento científico e por isso seu fundamento é científico", como ensina o professor doutor de Filosofia do Direito, 
Alysson Leandro Mascaro, desta Academia de Direito, em seu livro intitulado Introdução ao Estudo do Espiritismo.

E Alysson Mascaro continua:

\begin{abstract}
na verdade, inaugura-se com o Espiritismo não apenas um novo modelo religioso, mas sim um novo modelo de reflexão acerca do mundo, do conhecimento e da vida. $\mathrm{O}$ Espiritismo assenta-se numa perspectiva de conhecimento e reflexão nova, e seu aspecto religioso, bem como seu aspecto filosófico, são decorrências naturais e necessárias desta nova perspectiva científica e racional.
\end{abstract}

2. Espiritismo, Espírita e Espiritualismo

2.1. Os significados

O Vocabulaire Technique et Critique de la Philosophie, de André Lalande, ao consignar a Filosofia Espírita com a denominação de Espiritismo, acentua o seu caráter espiritualista. A seguir, ao tratar do termo spiritualisme, esclarece que é impróprio chamarse o Espiritismo de Espiritualismo como o fizeram os ingleses e, por vezes, os alemães.

Por quê? Porque o Espiritismo é apenas uma espécie do gênero Espiritualismo, como o Marxismo, por exemplo, é apenas do gênero Materialista.

O Livro dos Espíritos, de Allan Kardec, foi a primeira obra espírita, ocorrida no século XIX, considerada a primeira codificação do Espiritismo. O primeiro precursor do Espiritismo, na modernidade, foi Emanuel Swedenborg, nascido, em 1688, em Estocolmo, e desencarnado em Londres, em 1771. Swedenborg escreveu dezenas de obras e era médium de extraordinária capacidade, dentre elas a da vidência, deixando um legado de inúmeros ensinamentos que se assemelham às idéias preconizadas pelo Espiritismo, como o da imortalidade da alma, da possibilidade do intercâmbio mediúnico, do Perispírito e da descrição minuciosa de algumas realidades do plano espiritual. Ele foi o primeiro grande estudioso a se debruçar sobre os fenômenos mediúnicos e a aceitá-los.

Acrescenta-se, também, Andrew Jackson Davis, dos EUA, nascido em 1826 e desencarnado em 1910, possuidor de elevada capacidade mediúnica, com a qual foi o pioneiro na descrição da vida espiritual. Davis previu acontecimentos como os de Hydesville e do advento do Espiritismo, sendo um homem de destaque em épocas anteriores à codificação da Doutrina Espírita.

O Espiritismo é uma Filosofia Espiritualista. A codificação da Doutrina Espírita fez com que seu Autor, Allan Kardec, criasse vocábulos como Espiritismo para 
designar a doutrina propriamente dita e Espírita ou Espiritualista para identificar os adeptos do Espiritismo.

Sendo assim, Espiritualista é aquele que acredita haver em si algo mais do que a matéria, uma vez o Espiritualismo ser o oposto de Materialismo. O Espiritismo é Ciência, Filosofia e Religião que não surgiu para destruir ou combater as demais religiões; todavia, para ajudá-las na comprovação da imortalidade da alma.

Os princípios básicos da Doutrina Espírita são:

a. a existência de Deus;

b. a pluralidade das existências;

c. a preexistência e persistência eterna do Espírito;

d. a intercomunicação entre encarnados e desencarnados; ${ }^{2}$

e. as recompensas e perdas, conseqüências naturais dos atos praticados;

f. progresso infinito, por meio da comunicação universal entre os seres.

A ascendência ou influência do Espiritismo é oriunda do Druidismo, sistema religioso e filosófico vivido pelos druídas que, por sua vez, eram orientados pelos druída/druidesa, sacerdote/sacerdotisa gauleses e bretões. Os adeptos do Druidismo foram povos considerados de extrema inteligência e os primeiros na História da Humanidade a se pronunciarem por meio da manifestação mediúnica, comprovado, inclusive, cientificamente.

Atualmente, o Espiritismo apresenta-se como uma forma especial do processo do conhecimento. Uma vez superadas as fases anteriores de sua evolução, o homem apresenta-se apto a captar a realidade de maneira mais intensa. Desaparecidas as fases de embaraços da superstição mescladas ao campo visual do homem, o Espiritismo

\footnotetext{
2 As palavras encarnação e reencarnação estão sempre empregadas, praticamente, no mesmo sentido, pois o que interessa é a finalidade da vida do Espírito na fase transitória, como encarnado. Genericamente, pode-se dizer que "a encarnação é necessária ao duplo progresso, moral e intelectual, do Espírito: ao progresso intelectual pela atividade obrigatória do trabalho, ao progresso moral pela necessidade recíproca dos homens entre si" (O Céu e o Inferno, cap. III, n. 8). Na erraticidade, quando o Espírito está desencarnado, é quando ele examina o que fez, reconhece seus erros ou acertos, traça planos e toma resoluções para nova existência, onde se submete às provas (LE, 230). Esta nova existência, a reencarnação, portanto, não é uma punição para o Espírito, mas uma condição inerente à sua inferioridade. As reencarnações para os Espíritos, neste ou em outros mundos, mais ou menos adiantados ou evoluídos, têm finalidades diversas e específicas para cada um, conforme seja o plano ou meta a cumprir. Premissa final: Espírito encarnado traduz-se por aquele que tem missão a cumprir em vários mundos; Espírito desencarnado traduz-se por aquele que se encontra na erraticidade, estudando, refletindo ou trabalhando no Plano Maior, dada a pluralidade das existências. O Espírito não retrograda, somente evolui, de acordo com a sua capacidade de liberdade e de intelectualidade (as duas asas dos anjos, representadas aqui neste planeta pelos membros superiores, nossos braços); sua meta é a de chegar a mundos celestiais, às últimas etapas da sua evolução moral e espiritual. O Pai Todo-Poderoso mora em mundo celestial, significando que em certo período da nossa vida iremos encontrá-Lo!
} 
tornou-se mais claro e mais amplo. Assim que se posicionou liberto do temor de Deus e do Diabo, o homem se reconhece a si mesmo como inteligência autônoma, atuante na matéria. E assim, ao reconhecer isso, percebe que a dualidade Espírito-matéria, anteriormente percebida de maneira confusa, como vimos, esclarece-se. A inteligência humana é um poder atuante que supera, também, o mistério da morte.

O desenvolvimento e o treinamento da razão, por meio da Idade Média, e a conseqüente eclosão do racionalismo na Renascença, liberto das caquéticas emoções primitivas e das elaborações teológicas do misticismo, conferem ao homem a maturidade suficiente para enfrentar a realidade da vida, como ela é.

Os fenômenos anímicos e mediúnicos do passado podem ser agora examinados de maneira racional pelo Espiritismo. Por quê? Porque a captação da realidade já não é mais emocional. As categorias da razão definiram e aguçaram-se, permitindo uma captação totalmente direta, isto é, do aqui e do agora existenciais, sem a mescla das sensações confusas e emoções turbilhonantes do passado. A razão, dominando o caos das sensações e das emoções, equaciona de novo a realidade psicofísica: coloca o psiquismo humano e a realidade exterior sobre a mesa, para uma avaliação totalmente direta.

A partir desses acontecimentos, surge, em conseqüência dessa nova forma de captação e de julgamento do real, uma nova concepção do passado e do mundo. Essa concepção é ao mesmo tempo crítica e genética.

Do ponto de vista crítico, ela julga o passado, a antiga concepção e a também antiga posição do homem diante do mundo. Do ponto de vista genético, ela constrói uma nova concepção e uma nova posição. E aqui lembremos a Lei dos Três Estados, de Augusto Comte, pela qual poderemos dizer que a nova concepção se apresenta como uma síntese da oposição dialética entre o estado teológico e o estado positivo. E é por isso mesmo que a dualidade de conseqüências teria fatalmente de ocorrer.

Do desvínculo do estado teológico, ao adentrar no estado positivo, o homem tinha fatalmente de elaborar a sua concepção positiva do mundo, ou seja, a concepção materialista. No mesmo instante, porém, esta concepção surgia como oposição à concepção teológica. Isto é, o processo dialético se completa na síntese espírita: a concepção espírita do mundo reúne o misticismo teológico e o cientificismo positivo; daí a sua natureza de Espiritualismo-cientifico.

Julgar o mundo é avaliá-lo. A concepção espírita equivale a uma reavaliação do mundo. Diante dela, os antigos valores estão peremptos, caquéticos, superados. Também para a concepção materialista, os antigos valores tinham perecido. O materialismo substituíra os valores espirituais e morais pelos valores utilitários. Porém, o Espiritismo reformula os 
dois campos e modifica a posição de ambos. Os valores espirituais são reconduzidos ao primado do Espírito, mas os valores morais e materiais não são desprezados em absoluto ou, ainda, subestimados como na antiga mística.

Há aqui um novo critério valorativo: a Lei de Evolução. Este critério substitui, por um processo de síntese dialética, os dois critérios que anteriormente se opunham: o salvacionista e o pragmático. A salvação não está mais na fuga ao utilitário, porém no bom uso do utilitário, em favor da evolução.

Por fim, por Espiritualismo compreende-se a concepção, segundo a qual o real é de natureza absolutamente espiritual, enquanto que o mundo corporal é apenas uma aparência condicionada pela nossa consciência, ao apreendê-lo. O Espiritualismo não é somente uma concepção de existencialidade super-sensível; todavia, envolve um conjunto de conceitos éticos de sentido moral que, em si mesmo, define uma estrutura mental de elevado teor que transcende o campo da vida corporal. Sendo assim, não podemos, simplesmente, nos ater àquele conceito puramente biológico; é imperioso que ressaltemos, além do Ser corporal, o Ser Espiritual. É ele que nos oferece a realidade da existência espiritual, conseqüentemente ao sistema filosófico espiritualista que estamos vivenciando.

\subsection{As Quatro Revelações ${ }^{3}$}

Revelar significa extrair de sob o véu. Sendo assim, o progresso, as descobertas científicas e morais, o desenvolvimento do caráter humano podem ser considerados revelações, porque são véus que se levantam da ignorância, aproximando o homem da realidade das coisas do mundo e da vida.

As quatro revelações religiosas, a saber, a de Moisés, de Jesus Cristo, de Mohammed e a do Espiritismo, são profundos avanços para a condição humana, tanto no campo do conhecimento quanto no moral, cada uma adequada a seu tempo; todavia, todas imprescindíveis para o progresso da Humanidade.

E a Humanidade foi contemplada com essas quatro revelações: a primeira, quando da vinda de Moisés, também chamada de Revelação Mosaica. Nela, o Monoteísmo tomou forma e Deus foi apresentado como o Único Deus verdadeiro. Na segunda, quando do advento de Jesus Cristo; o Deus Único foi apresentado como o Pai Todo-Poderoso, o Pai de infinita misericórdia e amor, substituindo o Jeová dos Exércitos, rancoroso e

\footnotetext{
3 Na verdade, são três revelações contempladas na grade da Doutrina Espírita; todavia, este Autor acrescenta mais uma, por inserir e respeitar o Profeta Mohammed, que recebeu do arcanjo Gabriel os ditados do Qur'an, Livro Sagrado do Islamismo.
} 
vingativo. A terceira, a submissão total ao Deus Único, o Senhor que está sempre disposto à clemência, por meio do arcanjo Gabriel, designado a instruir o Profeta Mohammed. A quarta, com o advento do Espiritismo que teve como finalidade básica restabelecer, na Terra, as primícias dos ensinamentos dos profetas, principalmente de Jesus Cristo.

\subsection{Moisés}

Moisés era hebreu (israelita ou judeu), nascido em cerca de 1.250 anos a.C. Nessa época, os hebreus estavam escravizados no Egito e o Profeta concomitantemente havia sido criado entre os faraós, tendo uma educação do mais alto nível.

A História das Religiões nos ensina que Moisés ${ }^{4}$ libertou o seu povo da escravidão, fugindo do Egito e reconduzindo-o à Terra Prometida (Canaã). Cumpre salientar que o Profeta, já idoso, não pode adentrar os portões de Canaã, por desencarnar antes da glória cumprida; todavia, chegou a vê-la de longe e - num gesto emocionante inclinou a cabeça, tendo caído em seu semblante os longos cabelos grisalhos -, agradeceu a Deus!

Mais uma vez saliento, enfaticamente, que Moisés era médium e seus ensinamentos ao povo hebreu dividem-se em três partes:

a Lei Civil; a

Lei Divina e a

Lei de Talião.

A Lei Civil - Era um conjunto de normas que diziam respeito à educação e aos usos e costumes do povo hebreu ou, ainda, tratava-se de leis que atendiam às necessidades daquele povo saído da escravidão e sem controles social e educacional. As leis civis mosaicas versavam sobre os hábitos alimentares, de trabalho e de relacionamentos social e familiar. Todavia, leis aplicadas e compreendidas em seus conteúdos exclusivamente àquela situação de outrora, vivida pelos hebreus.

A Lei Divina - Está totalmente inserida nos Dez Mandamentos, ou Decálogo, que foram recebidos, por meio da mediunidade, por Moisés no Monte Sinai. Esses

\footnotetext{
4 Moisés havia enfrentado, na História da Bíblia, os problemas da mediunidade, a partir dos mistérios egípcios - incluso os das sete pragas notificadas ao faraó -, levando consigo pelo deserto um grupo de médiuns, à frente dos quais se mantinham ligações com o mundo espiritual. Jesus fizera o mesmo com o seu grupo de doze apóstolos, chegando ao episódio das materializações do Tabor e, mais tarde, das suas próprias manifestações em reuniões apostólicas. Todavia, para ambos, faltara a condição ambiente e a receptividade da mente humana para a compreensão exata do processo mediúnico.
} 
mandamentos são universais, na medida em que são a expressão de regras gerais e, dadas as proporções, atemporais, isto é, aceitas em sua maioria por toda a trajetória dos povos que compõem a História da Humanidade.

A Lei de Talião - Criada por Moisés, ${ }^{5}$ que a trouxe mediante a idéia de justiça. Embora primitiva atualmente, totalmente avançada para os padrões daquela época, principalmente para um povo, como o hebreu, repleto de ilimitação em suas ações. A Lei de Talião, modelo de justiça da época, punia os fatos delituosos ou errados com a mesma proporcionalidade: olho por olho, dente por dente, braço por braço.

As três leis tiveram a função de preparar o povo hebreu, por meio de Moisés, para a vinda do Messias, no caso o nosso Irmão Maior, Jesus Cristo, e tiveram, como premissa maior, a preparação tanto religiosa quanto social.

\subsection{O Cristianismo}

Durante toda a história do povo hebreu, havia profecias que anunciavam a vinda de um Salvador à Terra, tendo a missão de regenerar a Humanidade. Os hebreus eram dominados pelos romanos como a grande maioria das tribos que guerreavam com Roma que, por sua vez, expandia o seu Império por toda a Ásia Menor, Norte da África e Europa.

Jesus Cristo nasceu em Belém, nada deixou escrito, não fundou qualquer religião, seita ou templo, deixando tudo que ensinara - ou assimilara como o período que, supostamente, permaneceu junto aos essênios - aos seus discípulos e apóstolos, os quais se encarregaram de espalhar os ensinamentos cristãos. A Sua vinda foi tão marcante, que desde o seu nascimento, ano 1, é registrada a Era Cristã, sendo que a cronologia histórica se divide em antes de Cristo e depois de Cristo.

No percurso dos séculos, os cristãos agrupavam-se em igrejas; da mistura de conceitos cristãos aos pagãos do Império romano, originou-se a Igreja Católica Romana,

\footnotetext{
Moisés era egípcio. E conhecia a filosofia de sua terra quanto à vida após a morte, baseada no Livro dos Mortos. Os egípcios acreditavam que os Espíritos dos mortos iam para uma região subterrânea chamada Duat. Para entrar em Duat, o desencarnado tinha de passar por provas, a fim de demonstrar que tinha praticado o Bem. O deus supremo Osíris e sua mulher Ísis governavam Duat. Acreditava-se que ele tinha sido o primeiro faraó e que ensinara aos homens as artes da agricultura e da civilização. Seu filho, Horus, deus do céu com cabeça de falcão, cujos olhos eram a Lua e o Sol, guiava as almas até Duat. Quando os egípcios morriam, seus corpos eram mumificados para serem preservados, de modo que pudessem ser usados no outro mundo. Egípcios ricos eram enterrados com suas posses de valor, que poderiam usar em Duat. Os caminhos para Duat eram perigosos. Por isso, aprendiam encantamentos de um texto intitulado O Livro dos Mortos para se protegerem durante a jornada. E quando chegavam, seus corações - sede da consciência - eram pesados para determinar se haviam sido bons. Fragmentos desse livro são encontrados no Museu Britânico, Londres. Ressalta-se que muitos trechos são idênticos aos dos Dez Mandamentos.
} 
as igrejas cristãs ortodoxas e, por último, as igrejas protestantes. O Espiritismo, além do perfil filosófico, é também uma religião cristã, vinda do século XIX, resgatando os princípios e conceitos dos primeiros cristãos, sem a contaminação das hierarquias, ritos e regras desvirtuantes acrescidos, posteriormente, à idéia cristã.

O Cristianismo, como vimos, aparece na relação kardeciana como a Segunda Revelação na História das Religiões, personificado em Jesus de Nazaré, o Enviado, o Messias, o Ungido, chamado, também pelos gregos, o Cristo, vocábulo que significa “tudo isso e mais: aquele que há muito tempo era esperado pelos judeus".

O Cristianismo, nos primeiros séculos, foi constituído de núcleos que viviam os ensinos do Mestre na sua mais pura essência, escondidos nas catacumbas das cidades romanas, para se resguardarem da fúria dos perseguidores. Os chamados cristãos daquela época viviam uma vida desgraçada entre a dor, o sofrimento, o desespero e a angústia que a fé atenuava; porém, as forças iam minguando, em face da suscetível natureza humana. Era necessário retemperar as energias, animar as esperanças, reequilibrar a emotividade para que a semente e a seara fossem protegidas e a fé ganhasse novo rumo, sob o pálio de uma força generosa, que viesse em socorro.

E através de Flavius Valerius Constantinus I, o Grande - imperador romano que, após ter vencido rivais na Batalha de Andrinópolis, torna-se absoluto do Império romano -, é que o Cristianismo afloresce gloriosamente. O imperador convertera-se em 313; era pagão, adorador do deus-Sol, quando sua vitória na Batalha de Mílvia, empunhando a Lança Sagrada, o fez tornar-se cristão. Em seqüência, proclamara a liberdade religiosa e aboliu o suplício da cruz e os combates de gladiadores.

Cumpre salientar que o Cristianismo registra roteiro imenso de eventos gloriosos, testemunhos vivos de um conteúdo doutrinário que fez verdadeiros heróis da Espiritualidade, principalmente nos primeiros tempos, a exemplo do Rei inglês Ricardo I, um dos heróis protagonistas das Cruzadas. Depois, constituiu-se em Estado, elegendo uma estrutura complexa e uma hierarquia que vem até aos nossos dias, entre glórias e derrotas.

\subsection{Allan Kardec e o Espiritismo}

O Livro dos Espíritos, o primeiro livro de Allan Kardec, em sua abertura, estabelece os termos da inserção do Espiritismo no contexto religioso da modernidade. Com toda a sua especialidade, o livro contém a Doutrina Espírita; como generalidade, prende-se à Doutrina Espiritualista, uma das várias fases que representa. É cristalino que não se trata de uma doutrina que inaugura idéias novas, como afirma Allan Kardec: 
"a doutrina que os Espíritos ensinam [...] não é uma descoberta moderna, podendo ser encontrada, em fragmentos, na maioria dos filósofos da Índia, do Egito e da Grécia”.

$\mathrm{O}$ mesmo se traduz com relação às suas práticas, isto é, moda trazida dos EUA, em meados do século XIX, oriunda do fenômeno de comunicação com os desencarnados, por meio de objetos - mesas e cadeiras -, e médiuns e que já há alguns anos se difundira por toda a Europa; aliás, o próprio Allan Kardec teve o seu primeiro contato fenomênico dessa maneira.

A adoção do nome Allan Kardec, que se presume ser de origem celta, marca ritualmente a sua adesão a esses fenômenos, justificada por ele mesmo, que alega ter sido esse o seu nome em outra encarnação. Esta informação, também, havia sido obtida por meio de um Espírito, que com ele se comunicava. Allan Kardec, como passou a ser conhecido, era o pseudônimo do pedagogo francês Léon-Hippolyte Denizard Rivail, nascido em Lyon, em 1804, que já tinha à época, inclusive, alguns livros publicados, muitos de sua área, Pedagogia.

O saldo de sua trajetória foi que, acumulando material coletado - por meio de reuniões com médiuns, em sessões mediúnicas -, compõe um dossiê de pesquisas. Ao final de dois anos, todo o material acumulado já assumira a proporção de um livro, sistematizado e organizado por temas, sob a forma de perguntas e respostas. Vem à luz O Livro dos Espíritos, publicado em 1857, e uma nova versão, revista e ampliada, foi apresentada, em 1860, sendo então difundida no mundo todo.

Em O Livro dos Espíritos, a idéia sobre Deus e a formação do Universo são os temas de abertura. E ao inverso de outras cosmogonias descritas em livros de cunho religioso, o que se lê n'O Livro dos Espíritos não é o relato de um mito de origem. Como, também, não se trata de uma revelação divina a um mensageiro qualificado, seja ele um messias ou um profeta.

Logo de início, às primeiras páginas, o leitor se defronta com uma seqüência de perguntas e respostas. "Que é Deus?", solicita a primeira. Resposta: "Deus é a inteligência suprema, causa primária de todas-as-coisas”. Ou a pergunta de n. 4: “Onde se pode encontrar a prova de sua existência?" Resposta: "Num axioma que aplicas às vossas ciências. Não há efeito sem causa. Procurai a causa de tudo o que não é obra do homem e vossa razão responderá."

O modo formal e objetivo de formulação de perguntas, bem como a impessoalização e generalização das respostas, não deixam dúvidas quanto à inspiração de Allan Kardec, nos mesmos moldes positivistas da prática científica da época. Esta serviulhe mais do que como modelo de investigação. As correntes de pensamento científico da 
época foram apropriadas por Allan Kardec, como critério de validação das informações dos Espíritos.

Quanto à idéia da criação, Sandra Jacqueline Stoll afirma, com muita propriedade, em seu livro Espiritismo à Brasileira que:

Allan Kardec não descarta a idéia da criação, sustentada pela tradição bíblica. Mas busca uma posição conciliatória que pode ser resumida da seguinte maneira: 'ele mantém a idéia da criação divina do homem, porém, incorporando a possibilidade de se repensar a datação de sua origem. Postura que, como ele próprio explicita, não implica o questionamento da autoridade da Bíblia e, sim, de sua interpretação.' Ou seja, no que se refere às origens do Universo e da Humanidade, o texto bíblico, segundo ele, deve ser lido como metáfora.

Argumenta Allan Kardec, nesse sentido, que:

"Muitas descobertas já fizeram surgir dúvidas a tal respeito. Pode dar-se que, de um momento para outro, se adquira a certeza material da anterioridade da raça humana e então se reconhecerá, a esse propósito, [...] [que] o texto bíblico encerra uma figura". Ou seja, "os seis dias da Criação indicam [...] períodos, cada um de, talvez, muitas centenas de milhares de anos" (Kardec, [1860] 1997: 71-72).

A publicação d'O Livro dos Espíritos antecede em dois anos o lançamento da obra que viria consolidar o novo paradigma científico da época, A Origem das Espécies, de Charles Darwin.

Portanto, nesse primeiro livro de Allan Kardec, a idéia de uma origem comum a todas as raças humanas, tese defendida pelos monogenistas, não se coloca em estudo. A hipótese soava absurda.

Entre 1850 e 1870, a poligenia (condição do caráter determinado por vários genes) era a tese mais coerente e que predominava nos círculos científicos da Europa. Tratava-se de corrente do pensamento evolucionista do século XIX, que reunia pensadores fiéis à versão bíblica e que acreditavam que a Humanidade tinha se originado de uma fonte comum. Todavia, as diferenças físicas existentes entre as raças humanas e adaptadas aos climas e meio ambientes diversos eram consideradas como indício de criação independente. E por permanecer fortemente arraigada à versão bíblica, a concepção poligenista não teve muitos opositores e, assim, devidamente incorporada por algumas doutrinas religiosas da modernidade, dentre elas o Espiritismo. 
E no Espiritismo, observa-se mudanças no raciocínio de Allan Kardec, em relação ao tema, n'O Livro dos Espíritos, no qual a idéia da Humanidade, como criação divina, é confirmada com a idéia de uma origem comum das raças. Em $A$ Gênese, de 1868, publicado nove anos depois do lançamento de A Origem das Espécies, Allan Kardec retoma a discussão sobre a Criação da Humanidade, reproduzindo, em parte, a estrutura temática de seu primeiro livro; e neste último, dedica maior espaço à apresentação das recentes informações científicas relativas às origens do Universo e da Humanidade.

E assim, a sua posição pessoal é modificada com relação às idéias sustentadas em O Livro dos Espíritos. Ocorre uma atualização de certos pressupostos da Doutrina Espírita, em razão da incorporação de idéias que traduziam o pensamento das novas correntes que vinham se sucedendo e conquistando a hegemonia, no campo científico. Esse trabalho de revisão da doutrina em si é do próprio Allan Kardec, pois é ele quem acompanha, minuciosamente, o debate em torno das descobertas científicas da época, no intuito de promover a atualização da doutrina dos Espíritos.

E é essa posição que defende de maneira explícita na medida em que, constantemente, as suas obras afirmam ter a pretensão de manter o Espiritismo aberto às novas descobertas científicas.

Em $A$ Gênese, sua manifestação é enfática, quando assevera:

"Caminhando de par com o progresso, o Espiritismo jamais
será ultrapassado". E continua: "porque se novas descobertas
lhe demonstrassem estar em erro acerca de um ponto
qualquer, ele se modificaria nesse ponto. Se uma verdade
nova se revelar, o Espiritismo a aceitará".

A acomodação ao novo paradigma não se afigurava tão fácil. As novas teorias da evolução exigiam renúncia à idéia da origem divina do Universo, assim como ao lugar especial que se atribuía ao homem na Criação. Segundo o novo paradigma, a Humanidade como, também, as demais espécies de animais, tinham as suas origens e evolução regidas pelas leis da Natureza.

A idéia de uma origem diferenciada das raças humanas é própria da versão poligenista e, portanto, o que Allan Kardec sustenta é a de uma combinação de idéias que se sedimentam em versões concorrentes do evolucionismo. De um lado, defende a tese corrente entre os monogenistas de que a Humanidade teria uma origem única, a princípio divina, depois natural; de outro, mantém o argumento dos poligenistas, quanto à pluralidade de origem das raças que conformam o gênero humano.

Essa síntese produzida por Allan Kardec particulariza a versão espírita do tema, inserindo-o, de forma particular, no contexto do debate da época. A discussão 
em si, no entanto, é em um conjunto acessório; todavia, serve como parâmetro para se problematizar a origem e a evolução dos Espíritos com questões introduzidas à temática doutrinária propriamente dita, ou seja, o destino pós-morte, a reencarnação e a vida na erraticidade. E esses são os temas que dão continuidade aos capítulos d'O Livro dos Espíritos.

\section{A Ciência Espírita}

A origem do conhecimento espírita é científica. Sendo assim, toda a sistemática da Doutrina Espírita é respaldada nas realidades perceptíveis e analisáveis, sob o prisma de seu caráter científico.

A Ciência Espírita diferencia-se dos demais ramos do conhecimento humano por possuir, como objeto de estudo, os fenômenos espirituais. É a realidade do Espírito que fornece a razão de ser e suas peculiaridades à Ciência Espírita.

O Espiritismo, como Ciência, é alicerçado em objetos primordiais, como a existência e a vida do Espírito, a mediunidade e a relação entre as esferas material e espiritual. Tradicionalmente, estes objetos, acima especificados, foram e são legados ao campo do conhecimento religioso, do misticismo das superstições ou das especulações, sem que fossem analisados de maneira científica ou racional. Além disso, é o pioneiro no desenvolvimento científico dos temas espirituais, na medida em que passa a analisálos, segundo a ótica dos próprios fenômenos, sem buscar enquadrá-los nos modelos previamente estabelecidos pela Teologia, pelos livros sagrados ou pelas limitações de qualquer forma de conhecimento imposto.

Os fenômenos condizentes a esses objetos podem ser considerados como espíritas, ou melhor, fenômenos mediúnicos, desde a intervenção espiritual no processo de cura ou doença até a formação biológica e sua correlação com o Perispírito e o Espírito. A metodologia da Ciência Espírita é a mesma das demais ciências, fundada, principalmente, na experimentação e na comprovação empírica. E as técnicas desta Ciência são totalmente variadas, desde as análises de comunicação mediúnica até ao uso de aparelhos devidamente adequados à sensibilidade do Perispírito. ${ }^{6}$

\footnotetext{
6 Em observação ao Livro dos Médiuns (LM), "o Perispírito é um envoltório fluídico, semimaterial, que serve de elo de ligação entre a alma e o corpo; é o intermediário de todas as sensações que o Espírito recebe e pelo qual transmite sua vontade ao exterior e atua sobre os órgãos do corpo" (LM, 54). A alma nunca fica desligada do seu Perispírito. "Qualquer que seja o grau em que se encontre, o Espírito está sempre revestido de um envoltório, cuja natureza se eteriza, à medida que ele se depura e se eleva na hierarquia espiritual. De sorte que, para nós, a idéia de forma é inseparável da do Espírito e não concebemos uma sem a outra. O Perispírito faz, portanto, parte integrante do Espírito, como o corpo o faz do homem" (LM,55). Allan
} 
Assim como as demais ciências, a Ciência Espírita apresenta a possibilidade de evolução de seus postulados e estudos. O Espiritismo não é respaldado em dogmas; todavia, na evolução natural do pensamento e da compreensão humana.

Finalisando o tópico, uma das matérias mais interessantes sobre o Espiritismo é a inserida no acervo da Revista da Faculdade de Direito da Universidade de São Paulo, em seu fascículo de n. XXXIX, correspondente ao ano de 1938, de autoria do ex-professor de Direito Civil, Antonio Ferreira de Almeida Júnior, intitulada $O$ Espiritismo é uma religião? Já, naquela época no País, se discutia se o Espiritismo teria espaço em escolas públicas como Ciência de ensino religioso, que era contemplado em matérias de cursos ordinários em escalas primária, secundária, profissional e normal. Como diretor de Ensino do Estado de São Paulo, em 1938, o Autor da matéria e professor encontrou-se em situação sui generis ao ter de responder, oficialmente, à solicitação de pais de alunos, no sentido de autorizar os ensinamentos científicos do Espiritismo às crianças de uma escola primária. Reporto-me a essa matéria, de maneira específica pelo despacho proferido pelo ex-professor desta Academia de Direito ao tema Espiritismo, a qual recomendo ao leitor para ser lida por inteiriço!

\section{A vida após a morte}

Para o Espiritismo, secular é a de que a consciência humana sobrevive à morte do corpo carnal ou físico; para a Ciência, tenta-se há anos investigação auxiliada por meio da Física Quântica.

A maior experiência no Espiritismo é a de fatos relatados por indivíduos que sobrevivem nas chamadas experiências de quase-morte (EQMs) encontradas não-só pelos Espíritos de Luz como, também, pela confirmação de algumas crenças religiosas de várias culturas. Assim, quem as teve, descreve-as como uma passagem por um túnel que, por sua vez, conduz a um outro Mundo de Luz. Somos guiados, na maioria das vezes, por uma conhecida entidade espiritual, tradicionalmente uma pessoa próxima ou parente que já tenham partido.

Kardec afirma com propriedade que "como a semente de um fruto é envolvida pelo perisperma, o Espírito, propriamente dito, é revestido de um envoltório que, por comparação, se pode chamar de Perispírito". No Livro dos Espíritos, (LE, 93) há assertiva de que "o Espírito é envolvido por uma substância que é vaporosa para ti, mas ainda bastante grosseira para nós; suficientemente vaporosa, entretanto, para que ele possa elevar-se na atmosfera e transportar-se para onde quiser". Todavia, esta resposta dos Espíritos é genérica, porque a capacidade de um Espírito está condicionada ao grau de evolução de cada um, pois nem todo Espírito está em condições de volitar e transportar-se para onde quiser. 
O físico indiano Amit Goswami, da Universidade de Oregon, EUA, e pesquisador do Institute of Noetic Sciences há mais de trinta anos realiza pesquisa sobre EQMs; muitas delas relatadas em seu livro intitulado A Janela Visionária: um guia para a iluminação por um físico quântico.

Em um dos capítulos, Amit Goswami relata que

tanto nas visões no leito de morte quanto nas experiências de quase-morte, o indivíduo parece transcender a situação de morrer que, afinal, é freqüentemente dolorosa. Porém, parece experimentar um agradável e lúcido domínio da consciência.

Na verdade, esse tema para o Espiritismo não é novidadeiro, porque o Ser atuante se desliga do corpo vital ou carnal por meio de liames, conhecidos como cordões cor-de-prata, para um outro corpo semimaterial com perfil assemelhado ao do primeiro. Esse binômio é retratado no Espiritismo como Espírito/Perispírito. E salvo raras exceções, predominam todos os cinco sentidos que compõem a individualidade de cada Ser atuante; todavia, a consciência continua plena, nítida e ativa.

As experiências de quase-morte são encontros com a consciência não-local e seus arquétipos; é algo confirmado por dados diretos. Atualmente, desde 1999/2000, uma nova dimensão dessa pesquisa sobre EQMs, aplicada pelo físico Amit Goswami, demonstra que uma EQM pode levar a profunda transformação, no modo de vida do sobrevivente da experiência. A maioria deixa de sentir o medo da morte, que assombra a maior parte da Humanidade.

Para o Espiritismo, a morte não existe; trata-se de uma dádiva de Deus para que renovemos o Ser individual, seguindo em redemoinho de eterna evolução moral e intelectual e, enfaticamente, em uma evolução assemelhada à do Criador.

\section{A Filosofia Espírita}

A origem da Filosofia, com base em teorias milenares, está no primeiro pensamento do primeiro homem que primeiro filosofou, evidenciando a existência de um Eu filosofante, cujo ato consiste na atualização da potência que lhe corresponde. E essa potência é a essência humana que está inserida no ser humano à maneira da imagem e semelhança de Deus: o Autor que ao criar o homem o fez não de barro, mas de pensamento. 
E assim, o fez filósofo. Em premissa maior, o caminho certo e adequado é a atualização do filósofo que existe em cada ser humano. A Filosofia, em sua última realidade, é sabedoria e moral.

A História da Filosofia é a história do pensamento humano que tem como iter a perscrutar os problemas do Ser no decurso do tempo, elaborando o conhecimento que satisfaz o anseio de saber e encontra soluções compatíveis com a possibilidade das épocas e da capacidade intelectiva do homem na imensa problemática da realidade existencial.

E nesse redemoinho que se estende ao longo de 26 séculos, a partir do século VII a.C., o pensamento ávido e totalmente comedido vem através da Antigüidade clássica na Grécia, Jônia e regiões itálicas, construindo o que se intitula Realismo, concepção filosófica que assegura às coisas em si a existência com absoluta independência.

Em seguida, o pensamento da Idade Média, sem realizar propriamente filosofia; todavia, exercitando-se para atuar em nova dimensão. Paralelamente, surge a gloriosa Idade Moderna, trazendo consigo o conceito de Idealismo, alterando significativamente o cenário filosófico e dando primazia ao $\mathrm{Eu}$, investindo-o de dignidade ante a qual as coisas perdem o seu ser em si e por si, para se tornarem tão-somente conteúdos de consciência do sujeito cognoscente.

Mediante o quadro anterior, o Idealismo se verte por meio dos refolhos do pensamento dos filósofos que se seguem na fieira do tempo, assumindo posição sempre mais ampla e refinada, até que Emmanuel Kant o entrelaça com o Realismo, restaurandolhe as prerrogativas perdidas em uma dialética em que as coisas se ajustam e se superam mutuamente, cuja sintese concorre terminantemente ao estabelecimento da Filosofia da Existência. Mas agora em plena contemporaneidade junto a Nietzche e Kierkegaard e seus principais representantes no século XX: Heidegger, Jaspers, Grisebach, Kritische, JeanPaul Sartre, Gabriel Marcel e outros.

A História da Filosofia, propriamente dita, afigura-se-nos como o melhor e mais propício meio para se tomar contato com a Filosofia. Como, também, adestrar o pensamento ao trato com sua temática, seu processo de reflexão acerca do Ser, nas regiões ontológicas e metafísicas, naquilo que sempre somos forçados a nos embrenhar para conhecer, exercitando a nossa habilidade.

E nesse contexto, abrindo série de caminhos que nos conduzem à Filosofia Espírita da Existência. Por quê?

Porque o Existencialismo, cuja sistemática destina o homem à morte, exclusivamente, nos põe um ponto final a todas as razões que motivam a vida com o 
dogma da salvação por obra de um Ser Superior, abolindo, e mesmo anulando, o valor próprio de cada um de nós.

Sendo assim, alienando o homem, exige a necessidade da substituição da Filosofia insuficiente por outra, que saiba distender, para além de todas as fronteiras, o pretérito obscuro e longínqüo e o futuro rutilante na dimensão do infinito.

A Filosofia Espírita, como existência conceptual, manifesta uma inegável e irredutível facticidade que é a conseqüência da estrutura palingenésica ${ }^{7}$ da Humanidade que a edifica, a partir da preexistência da alma e sua sobrevivência além da morte, nas dimensões infinitas do existir física ou metafisicamente, isto é, fora do tempo, biologicamente no espaço, espiritualmente fora dele.

Em premissa final, do primeiro pensamento filosófico de cada ser humano projeta-se o Espírito Eterno, multiplicando-se, sem solução de continuidade, para a realidade substancial da própria natureza.

A Filosofia procura, pela sua essência, desobstruir o conhecimento daquilo que não se mede, não se pesa, não se cheira nem se sente ou se ouve; enfim, o que não é tangível. Isto porque a Filosofia só assevera o que é abstrato, denominada por ela mesma de Metafísica, ou melhor, o que está além da Física; portanto, fora da sintonia sensível dos sentidos.

A gnosiologia ${ }^{8}$ e a ontologia ${ }^{9}$ são os seus mais importantes instrumentos no âmago incomensurável do Universo abstrato, à luz da razão pura e da intuição. São a Teoria do Conhecimento e a Ciência do Ser.

Os antigos filósofos procuraram dividir a realidade existencial em dois mundos, a saber: o sensível e o inteligível.

Nesse contexto, era necessário sair de um para entrar em outro num exercício totalmente confuso. Depois, o grego Aristóteles anulou essa dicotomia, reunindo-os em uma única unidade, porém o senso da dualidade não se apagou; pelo contrário, antes persistiu e continua persistente a desafiar cada vez mais no pensamento em si e com total intensidade.

Advém o teorema: o que é afinal o pensamento senão uma realidade dual?

O pensamento propriamente dito, em si mesmo, é um atributo inalienável do Ser pensante, o Eu, e o conteúdo do pensamento ou aquilo que ele contém. Enfim,

\footnotetext{
7 Adjetivo de palingenético, relativo à palingenesia; na Filosofia, eterno retorno, renascimento sucessivo dos mesmos indivíduos.

8 Oriunda de gnose, do grego gnôsis, significa ação de conhecer.

9 Ontologia faz parte da Filosofia que trata, por sua vez, do Ser enquanto Ser.
} 
nele coexistem duas coisas distintas, intimamente interligadas, que se confundem e se completam entre si. Mérito de tudo: um não é sem o outro.

Traduz-se como o pensador - o Eu pensante -, o Espírito como Ser nãoabsoluto mas o infinito-relativo, imerso no Ser biológico, o corpo, através do qual se manifesta no mundo corporal ou material. E na dimensão espiritual, o pensamento estende ainda mais amplamente a grandeza de sua natureza tributária na comunicação.

Percebe-se, assim, que a Filosofia Espírita está mergulhada em suas próprias águas de infinito oceano azul, como ensinara o professor Manoel Pelicas São Marcos, da Federação Espírita do Estado de São Paulo (FEESP), do qual fui aluno: “os seus temas estão na conexão do mundo material e do metafísico, haja vista que a vida extravasa do mundo espiritual para o material e deste para aquele, tendo, por liame, o Ser igual ao Espírito ou ambos identificados na imensa fenomenologia que as duas dimensões ensejam. E é aqui que a Ciência Espírita tem a sua insubstituível função".

E é também, desta maneira, que a Filosofia Espírita tem sua base na concreção fenomênica, para se lançar, amparada nessa certeza, no infinito acontecer da realidade universal jungida ao cognoscente que, por sua vez, busca o cognoscível; na relação de sua competência para realizar os possíveis essenciais que a contemporaneidade descerra no horizonte. E assim, a Filosofia Espírita se introduz no cenário da realidade assinalada pela Filosofia da Existência, passando a desempenhar o seu mais elevado trabalho ou a sua maior e grandiosa missão.

A Filosofia Espírita é a reflexão racional, a respeito da existência e da criação da natureza do ser humano, infinita e espiritual, cuja condição de vida é a somatória de todas as suas experiências adquiridas em inúmeras situações vividas no Plano Espiritual e nas suas várias encarnações.

A razão é o diferencial entre a Filosofia Espírita e outras formas de conhecimento ou de crença com a fé. Ao contrário das demais reflexões racionais humanas, a perspectiva filosófica espírita vislumbra realidade existencial não considerada por outras filosofias. A racionalidade espírita engloba as realidades da imortalidade da alma, da reencarnação ${ }^{10}$ e da justiça divina, como pondera Alysson Leandro Mascaro, professor doutor desta Academia de Direito.

\footnotetext{
${ }_{10}$ A reencarnação representa um atestado eloqüente de que tudo que vem de Deus é sábio e justo, porque, por ela, não há necessidade de a alma retomar o seu antigo corpo, uma vez que o Espírito tem sempre diante de si a oportunidade de adquirir um novo organismo, reencarnando tantas e quantas vezes forem necessárias para colimar o seu aperfeiçoamento espiritual, aproximando-se cada vez mais de Deus. Os Evangelhos corroboram, de sobejo, a crença na reencarnação: Jesus Cristo foi bastante incisivo na afirmação de ter sido João Batista a reencarnação do Profeta Elias. Os evangelistas descrevem essa afirmação, de modo a não deixar qualquer dúvida: "E os discípulos lhe perguntaram, dizendo: Pois por quê dizem os escribas que importa vir Elias
} 
Em suma, a Filosofia Espírita é dialética; traduzindo, explica a realidade por meio das suas próprias contradições. $\mathrm{O}$ aparecimento das ciências e seu desenvolvimento colocaram o homem diante da realidade objetiva. Essa realidade afugentou os fantasmas da superstição; todavia, ao mesmo tempo, facilitou a compreensão do fenômeno mediúnico. Se, por um lado, as pessoas mais apegadas ao plano físico negaram a existência de vida além da matéria, por outro, as mais desapegadas foram capazes de interpretar a mediunidade de maneira racional. A conseqüência apresentou-se de maneira dupla, a saber: surgiu o materialismo, porém surgiu, também, o Espiritismo-científico.

E o Espiritismo-científico apresenta-se como um processo gnoseológico, ou melhor, como uma forma especial do Processo do Conhecimento. Superadas as fases anteriores da evolução, o homem torna-se apto a captar a realidade de maneira mais intensa. Desapareceram os embaraços da superstição e o campo visual do homem tornou-se mais claro e mais amplo. Enfatizando: liberto do temor a Deus, o homem reconhece-se a si mesmo com uma inteligência autônoma, atuante na matéria. Ao reconhecer isso, percebe que a dualidade Espírito-matéria, anteriormente percebida de maneira confusa, esclarecese. A inteligência humana é um poder atuante que supera, também, o mistério da morte.

\section{O Direito Natural}

\subsection{Breve histórico}

Remontando à Antigüidade, pode-se dizer que foi no século VI a.C. que a Filosofia grega se manifestou. Dois séculos mais tarde, atingiu o apogeu com Platão e Aristóteles, figuras exponenciais. Desde essa época, o problema do Direito Natural tem sido abordado como objeto de certa preocupação filosófica, como nos ensina o exprofessor doutor Antonio Carlos de Campos Pedroso, desta Academia de Direito.

Alguns historiadores remontam a noção de Direito Natural a Heráclito, pré-socrático do século VI a.C. Segundo a tradição, esse filósofo reconhecia a existência da ordem universal (o devir não é anárquico, mas está dominado por uma medida, um "logos", um sentido) e considerava ter o homem de harmonizar a sua atividade, seu agir

primeiro? Mas Ele, respondendo, lhes disse: Elias certamente há de vir, e restabelecerá todas as coisas: digovos, porém, que Elias já veio, e eles não o conheceram, antes fizeram dele quanto quiseram. Assim também o Filho do homem há de padecer às suas mãos. Então conheceram os discípulos que de João Batista é que Ele lhes falara". (Mateus, 17:10-13; Idem em Marcos, 9:10-12). Não há, em suma, melhor testemunho sobre a reencarnação, porque se ela aconteceu com o Profeta Elias, acontece com todos os Espíritos. Além disso, uma análise bastante superficial, revela a superioridade da lei da reencarnação sobre a teoria da vida única do Espírito na carne. 
- com esta medida -, surgindo, assim, princípios de conduta ou normas sociais (naturais). Trata-se, portanto, de um ponto de vista metafísico, não havendo uma doutrina à respeito do Direito Natural.

Cumpre também assinalar a posição dos sofistas, os quais salientavam a relatividade das normas jurídicas (positivas) provenientes das convenções humanas. Apesar disso, não havia o Direito Natural: por natureza, nada é verdadeiro, tudo é derivado do homem - sentido de todas as coisas -, na expressão de Protágoras. E neste tópico, já há uma diferenciação, em parâmetro a Heráclito, que preponderava a mencionada linha do pensamento pré-socrático. Mas, os pré-socráticos não chegaram a apresentar um corpo de leis e doutrinas sobre a questão, apesar de suas cogitações. É oportuno lembrar que, nessa época, o maior espetáculo para o homem era o próprio homem.

E nesse redemoinho filosófico, volta-se à cultura grega no momento em que surgiram as figuras exponenciais de Platão e Aristóteles. E é aqui que a preocupação começa a tomar relevo, isto é, tanto aquele quanto este pensaram em colocar a Lei Natural como fundamento de suma importância no estudo e na interpretação do Universo.

Para Platão, o fundamento ontológico da Lei Natural encontra-se no arquétipo, ao qual todas as coisas deveriam se conformar, daí surgindo a noção de normalidade. A idéia de Justiça deriva da idéia do Bem, a qual se submete à idéia divina da ordem jurídica universal. Trata-se de um Direito Natural ideal, proveniente da contemplação das idéias. E as idéias eternas estão preordenadas pela mente divina, vinculando-se a elas todo conhecimento do justo e do injusto.

Para Aristóteles, as noções de universal e de normalidade persistem; segundo o filósofo, é sobre a essência imutável dos seres que se coloca a idéia da Lei Natural. As idéias não são transcendentes - como pretendia Platão -, são imanentes aos seres. E todos os seres se compõem de matéria e forma, sendo esta última o princípio que determina o modo de ser; a forma é a idéia ou o fim a que todos os seres tendem: $a$ essência de todas as coisas. Ora, a essência, sendo percebida como universal e pertencente a todos os indivíduos que constituem uma categoria de seres, exige um comportamento definido, expresso em imperativos naturais; traduzindo, este é o conceito teleológico de natureza.

Premissa final: um direito existe ligado às exigências naturais do homem, ao lado de um direito de cada sociedade; aquele, é de caráter necessário, universal e imutável; este, de caráter contingencial e variável. Um é justo por natureza e outro, por convenção. E esta concepção é retomada e aprofundada, posteriormente, por Santo Tomás de Aquino. Para Santo Tomás, uma coisa é boa, quando ela pode ser considerada perfeita; perfeito, 
por seu turno, é tudo aquilo que nada falta. É o que é por sua forma que, por sua vez, determina a sua essência. Na Filosofia tomista para que algo seja perfeito e bom, deverá reunir, simultaneamente, a forma que lhe contém, seus antecedentes autênticos e seus conseqüentes naturais.

Este pensamento anterior sucedeu ao dos céticos, no período da Filosofia helenístico-romana. Pertencente aos séculos II e III a.C., oposicionistas aos céticos levantaram-se os estóicos, reafirmando com tenacidade o vigor de Direito Natural, insistindo na idéia de que os homens têm direitos e deveres independentemente das leis positivas e na de que estas leis positivas para serem justas deveriam obrigar a linha reta das consciências de cada Ser.

O nosso ordenamento jurídico, o Direito Positivo, tem evoluído por meio dos tempos; todavia, encontra-se muito distante dos princípios da verdadeira Justiça. O Direito da Força ainda prevalece sobre a Força do Direito; o orgulho e o egoísmo são forças terríveis que orientam os legisladores, cegando-os e impedindo-os de verem a verdade.

Sendo assim, a Justiça do Direito Positivo não se identifica com a Justiça do Direito Natural Espírita: enquanto a primeira busca seus postulados na Ciência da Matéria, a segunda apóia seus princípios na Ciência do Espirito. Ciência esta que só é possivel atingir com o aperfeiçoamento moral da Humanidade que, por sua vez, só será alcançado com o conhecimento das leis naturais, de ordem moral, reveladas pelo Espiritismo e codificadas, cientificamente, por Allan Kardec, pela observação dos fatos paranormais e das conseqüencias filosóficas e morais dos mesmos.

Sabemos que o conhecimento é o maior patrimônio do ser humano, como assevera Sócrates de "quem conhece não erra" ou a assertiva de Jesus Cristo de que "conheça a verdade e ela vos fará livres". Mas o conhecimento real só se obtém com o estudo integrado do triângulo Ciência, Filosofia e Religião, uma vez essas áreas terem origem única: a Lei Natural Divina, traduzida por Deus: Causa Primária de Todas-asCoisas, Inteligência Suprema do Universo ou o Supremo Legislador.

Nos meados do século XIX, a Filosofia do Direito foi denominada Direito Natural ou Teoria do Direito Natural. Essa primeira denominação é atribuída geralmente a Pufendorf (1632-1694) que a empregou no tratado de sua autoria intitulado De jure naturae et gentium (1672).

A expressão Direito Natural - que atualmente caiu em desuso para designar a Filosofia do Direito - já indica, de certa maneira, o caráter crítico dessa disciplina. Os estudos de Direito Natural contrapõem-se aos do Direito Positivo ou Direito vigente em 
cada país, que constituem a Dogmática Jurídica. Esta se ocupa do Direito que é; o Direito Natural do que deve ser.

O Direito Natural do século XIX, denominado Clássico, não se apresenta como uma duplicata do Direito Positivo, mas se resume em alguns preceitos que, sendo base da vida prática, condicionam, também, o mundo jurídico. Para os filósofos e orientadores do Direito Natural Clássico, este não é senão a Moral mesma, enquanto serve de pressupostos ao Direito, expressando, por conseguinte, certos princípios gerais de conduta, como exigências imediatas da racionalidade humana. Sendo assim, essa concepção de Direito Natural é muito diversa da dominante, a partir do Renascimento, desde Hugo Grócio (1583-1645) e seus continuadores e opositores, como Tomás Antonio Gonzaga, os quais converteram o Direito Natural em verdadeiro Código da Razão, capaz de conter a priori soluções adequadas para todos os problemas jurídicos emergentes da experiência concreta.

São Tomás de Aquino (1124-1275) nos delegou o seguinte aprendizado:

É sabido que a idéia de um Direito Natural, já poderosamente afirmada na corrente socrático-aristotélica e na estóica, assim como na obra de Cícero e de jurisconsultos romanos, adquire um sentido diverso nas coordenadas da cultura cristã, não-somente por tornar-se uma lei da consciência, uma lei interior mas, também, por ser considerada inscrita no coração do homem por Deus. O Direito Natural destinava-se a representar a afirmação da nova Lei contra a Lei Velha, a mensagem instauradora de uma nova forma de vida. ${ }^{11}$

O Renascimento marcou o despertar da cultura para um novo mundo de valores, que é dominado pela idéia crítica de redução do conhecimento a seus elementos mais simples. Enquanto na Idade Média existia um sistema ético subordinado a uma ordem transcendente, o homem renascentista procura explicar o mundo humano tãosomente segundo exigências humanas. Essa explicação opera-se mantendo-se os autores fiéis a certos pressupostos medievais, como acontece na doutrina do filósofo Grócio, da Holanda.

Na obra do filósofo holandês há uma passagem característica, na qual declara que a justiça possui fundamento de razão, de maneira tão-inamovível, que ela existiria mesmo que, por absurdo, Deus não existisse. E embora afirmada a existência

${ }^{11}$ Esse trecho é extraído do livro de QUEIROZ, José Fleuri. Filosofia do direito: a justiça pura e completa. Código de Direito Natural Espírita. Código Fleuri. São Paulo: Editora e Distribuidora de Livros Mundojurídico LTDA., 2006. 
de Deus, não é essa a idéia que decorre a legitimidade da ordem justa. É justa, sim, por expressão de ditames da razão.

Mérito final: os pensadores, depois de Grócio, não sentiram mais necessidade de fazer qualquer referência cautelosa a valores transcendentes, preferindo explicar o universo jurídico e político, segundo dados estritamente humanos. Só a razão, como denominador comun dos humanos, parecerá manancial de conhecimentos claros e distintos, capazes de orientar melhor a espécie humana, que quer decidir por si o seu destino.

E é assim que surge, no campo do Direito, um movimento que ocupa mais de três séculos na história do Ocidente, sob a rubrica ambígua de Escola do Direito Natural, abrangendo um número de pensadores, inclusive alguns dos maiores Espíritos da chamada civilização burguesa.

A Escola do Direito Natural ou do Jusnaturalismo distingue-se da concepção clássica do Direito Natural aristotélico-tomista por este motivo principal:

Enquanto para Santo Tomás primeiro se dá a "lei" para depois se pôr o problema do "agir segundo a lei", para aquela corrente põe-se primeiro o "indivíduo" com o seu poder de agir, para depois se pôr a "lei".

Para o homem do Renascimento, o dado primordial é o indivíduo, como ser capaz de pensar e de agir. Em primeiro lugar está o indivíduo, com todos os seus problemas, com todas as suas exigências. E é da autoconsciência do indivíduo que vai resultar a lei. E mais: é por isso que surge a idéia de contrato. O contratualismo é a alavanca do Direito na época moderna.

Por que existe a sociedade? Porque os homens concordaram em viver em comum. Por que existe o Direito? Porque os homens pactuaram viver, segundo regras delimitadoras dos arbítrios, respondem os jusnaturalistas.

\subsection{O Direito Natural no mundo moderno}

O mundo moderno é o período histórico que vai do século XVI aos fins do século XIX. Tem uma fisionomia profundamente diversa dos períodos anteriores, inclusive no que concerne com o modo de conceber o Direito Natural.

A atmosfera espiritual do mundo moderno é caracterizada pelo que recebeu do Renascimento e desenvolveu poderosamente, isto é, a crença no valor do homem individual e nas suas potencialidades. O dinamismo que essa idéia comunicou aos homens 
foi algo gigantesco, que se comunicou a todos os ramos da cultura e da existência, aliás vindo até hoje.

Quanto ao exercício da inteligência, duas idéias foram o seu motor: a de que a razão humana pode chegar sozinha à verdade e usar desta em beneficio do homem; e a de que as ciências devem ocupar-se com coisas e fatos concretos ... e não com abstrações. Essas idéias tiveram aplicação na Filosofia do Direito e, na verdade, plasmaram o Direito Natural dos tempos modernos, sob todos os seus aspectos.

No mundo moderno, o Direito Natural tem uma concepção sui generis, a saber: é um Direito Natural

\begin{abstract}
leigo, feito por filósofos laicos e não por teólogos - os quais praticamente saíram de cena;

racional, porque só usa do que lhe dá a razão humana e não os Deuses ou a Revelação Divina - , trabalhando somente sobre a natureza humana (e não mais sobre o universo e a vida transtemporal);

pragmático (preocupado em obter verdades aplicáveis na prática), em benefício do homem individual (personalismo que pode cair em individualismo), visando a assegurar a sua liberdade (liberalismo), pois é titular de direitos anteriores (inatismo) ao Estado, sendo que este resulta (voluntarismo) de um pacto ou contrato social (contratualismo) dos cidadãos que o criam.
\end{abstract}

Essas são as notas distintivas mais presentes no Direito Natural moderno. Evidentemente, há as grandes contribuições de marca pessoal de seus grandes autores. E ao lado de exageros e erros há, sobretudo, ao longo do período, o fluir das correntes do equilíbrio, enriquecedoras da visão jusnaturalista.

Finalisando, Lutero (1483-1546) ensina que só a fé dá a salvação e só têm fé aqueles a quem o Pai Todo-Poderoso a deu, e por isso estão predestinados à salvação. A estes não se aplica o Direito Natural, pois agem sempre bem. Aos outros, aos maus, é que ele se destina, para intimidá-los ou castigá-los com penas: assim, a coação ou sanção não é um momento ou elemento do Direito, mas é a sua substância mesma.

Calvino (1509-1564) estabelece que, ao cristão perfeito, o Direito Natural é um sentimento da consciência, que discerne o bem do mal. Quanto aos corruptos, nãopredestinados pela Graça Divina, foi necessário de que Deus, pelo Decálogo ou Lei Revelada, lhes ensinasse o Direito Natural. Ademais, dada a maldade da grande maioria dos homens, deve haver um Direito Positivo, que assessore na aplicação da Lei Divina, afastando, o que dificulta ou impede esta. O Poder deve ser teocrático e forte. 
O Direito Natural, conclusivamente, é o cômputo geral do que o ser humano assimila da natureza e dela (natureza) o ensina que o homem e a mulher devem se educar, casar, procriar, repassar ensinamentos. Usos e costumes de vivência individual vindos dos romanos, dos quais, como premissa final, conclui-se, também, de que a existência humana tem uma só missão de suma importância: a preservação da espécie. E, convenhamos, disto ninguém duvida!

\subsection{O Direito Natural Espírita}

A Doutrina Espírita ensina em O Livro dos Espíritos, na pergunta de n. 01 que “Deus é a Inteligência Suprema, Causa Primária de Todas-as-Coisas”. Nesse mesmo capítulo, de forma racional, toma-se consciência da existência de Deus, por meio do conhecimento da Lei de Causa e Efeito: "Procurai a causa de tudo o que não é obra do homem e vossa razão vos responderá”. (O Livro dos Espíritos, pergunta de n. 04). Pela obra, se conhece o artífice.

Percebe-se que a harmonia, reguladora das atividades do Universo, revela uma força inteligente. Atribuir a origem da vida ao acaso seria um contra-senso, pois o acaso não produz efeitos inteligentes. As limitações humanas permitem tão-somente vislumbrar alguns dos atributos do Pai Todo-Poderoso: eterno, imutável, imaterial, único, soberanamente justo e bom.

Existe uma Lei Divina, ou Natural, regendo, supervisionando as coisas, atuando no Plano Divino da Criação, impulsionando, automaticamente, a vida: a evolução do princípio espiritual inteligente. Esta Lei Natural é também eterna, imutável, perfeita, como o próprio Deus; reflete o Criador. A harmonia que rege o Universo material e o Universo espiritual está fundada sobre a Lei Natural, que é a única e a verdadeira para a felicidade do homem. A Lei Natural indica o que deve ou-não fazer. E o homem é totalmente infeliz, quando se afasta dela.

As leis humanas, ao contrário, são mutáveis, temporárias, variam de um Estado para outro, reflexos da realidade imperfeita do próprio homem, que ainda está longe da perfeição. Por isso, é que a Misericórdia e a Sabedoria do Pai estabelecem a Reencarnação, pois que, conforme todos percebem, uma só existência não é suficiente para vencer a longa caminhada entre o selvagem e o civilizado, entre o ignorante e o sábio, entre o perverso e o santo, como nos ensina o professor doutor José Fleuri Queiroz, Autor de Filosofia do Direito, O Código de Direito Natural Espírita, referendado no final deste trabalho. 
Entre as leis naturais, umas regem o movimento e as relações com a matéria bruta - são as leis físicas; seu estudo pertence ao domínio da Ciência Acadêmica. Outras, concernem, especialmente, ao homem em si mesmo e às suas relações com Deus e com os seus semelhantes, compreendendo as regras da vida do corpo como, também, as da vida da alma - são as leis morais. Essas explicações são encontradiças no Livro dos Espíritos, 617-a. As leis naturais, ou divinas, atuam automaticamente, impulsionando a evolução, estão escritas na consciência do Ser e é por isso que todos os seres humanos têm condições de conhecê-las.

Todavia, essa compreensão é proporcional ao grau evolutivo do Espírito. Todos, entretanto, as compreenderão perfeitamente um dia, impulsionados pela Lei do Progresso que é integrante às dez partes divididas para melhor assimilação. Dentre as dez, a pergunta de n. 648 de O Livro dos Espíritos a apresenta, a saber: leis sobre adoração, trabalho, reprodução, conservação, destruição, sociedade, progresso, igualdade, liberdade e, por último, leis de justiça, amor e caridade. Cumpre salientar que esta divisão é meramente pedagógica.

A cada nova existência, aumenta a bagagem espiritual do homem, nas experiências sucessivas com o Bem e o Mal. A explicação lógica da Doutrina Espírita é que, por meio da Reencarnação, revela-se a justiça de Deus. Por isso, a importância de acontecer, de tempos em tempos, uma nova revelação espiritual, um novo chamamento, para o homem lembrar a Lei Natural, já que a esqueceu ou a aprendeu imperfeitamente. Daí a razão de os Espíritos missionários se reencarnarem com o objetivo de fazer a Humanidade avançar em todos os campos de conhecimento: religioso, fílosófico, artístico, científico etc.

E é indispensável e indiscutível a utilidade dos ensinamentos da Doutrina Espírita, claros e inequívocos, para que ninguém possa pretextar ignorância. Os Espíritos vêm preparar o Reino anunciado por nosso Irmão Maior: Jesus Cristo, quando a Justiça deve prevalecer. E a Justiça é a virtude de dar a cada um aquilo que é seu. É o respeito aos direitos de cada um. O sentimento de Justiça é natural e está no coração do homem justo.

Em Filosofia do Direito, o emérito professor titular Goffredo da Silva Telles Junior, desta Academia de Direito, do qual fui aluno, elucidando à indagação de "o que é a Justiça?", nos ensina:

não é fácil definí-la. De todas as realidades ligadas às normas sociais, talvez seja esta a de mais difícil definição. Dizemos 'fazer Justiça', e sabemos intuitivamente o que estamos dizendo. 'Fazer Justiça' significa 'Fazer com que alguém tenha o que é seu'. Significa 'atribuir o seu a quem 
o seu pertence, em conformidade com a norma social'. Empregamos aqui a expressão 'dar a outrem' em amplo sentido. Ela significa 'fazer ou abster-se de fazer, em benefício de outrem'. Significa, inclusive, não prejudicar a outrem'.

Em Filosofia do Direito, o emérito e saudoso professor titular Miguel Reale, do qual fui aluno, desta Academia de Direito, nos esclarece que:

a Justiça é vista por uns pitagoricamente como expressão de harmonia aritmética, como proporção. Por outros, como força que liga entre si os astros e os corpos, como aquela força que determina a passagem do caos para o cosmos. A natureza é harmônica e cósmica, porque presidida pela divindade suprema, segundo os 'conselhos' de Têmis, que de Júpiter gerou a filha Diké, a deusa dos julgamentos, a deusa vingadora das violações da lei. Por ser a Justiça um alvo a ser atingido, surgiu a noção do Direito como algo que traça uma direção, como comportamento, enquanto dirigido para o ideal personalizado em poderosa divindade. Nessa intuição, o elemento mítico se entrelaça, de maneira prodigiosa, como a experiência humana empírica. É desnecessário lembrar aqui a importância dos mitos na formação do saber humano. Platão e Aristóteles já puseram em altíssimo relevo a importância dos mitos para a Ciência, mostrando o papel que representam as hipostasizações do homem no processo do conhecimento, porquanto representam maneiras de penetrar no âmago da realidade, naquilo que a realidade tem de mais oculto. Podemos, pois, dizer que a primeira intuição do Direito foi em termos de Justiça ou, se quisermos empregar palavras de nossos dias, em termos axiológicos. Este sentimento do Direito como Justiça, como valor, como ideal, implicava a idéia de obrigatoriedade, de comando, tanto assim, que o ideal se divinizou; e a Justiça foi predicado atribuído à própria divindade.

Premissa final: Direito como Justiça! Justiça como Direito! Justiça foi predicado atribuído à própria divindade! O Direito Natural postula que o princípio de Justiça encontra-se na consciência do homem que, por parâmetro, é a marca do Criador na criatura, como Descartes definira em suas obras, dentre elas Discurso do Método/ Meditações Filosóficas. ${ }^{12}$

\footnotetext{
${ }_{12}$ Na noite de 10 de novembro de 1619, René Descartes, então jovem soldado acampado em Ulm, Alemanha, sentiu-se tomado por intensas agitações. Seu amigo, biógrafo e correspondente, Abade Baillet, diria mais tarde que ele "entregou-se a uma espécie de entusiasmo, dispondo de tal maneira do seu Espírito cansado, que o pôs em estado de receber as impressões dos sonhos e das visões". De fato, Descartes que se preocupava demasiado com a incerteza dos conhecimentos humanos, transmitidos tradicionalmente, deitou-se para dormir
} 
Desejar a outrem o que se deseja a si próprio não seria nada difícil, caso o orgulho e egoísmo não estivessem tão arraigados nos corações humanos. Entretanto, no processo evolutivo permanente, o Espírito imortal vai conciliando, por meio da educação, sua lei transitória à lei eterna e imutável, oriunda da divindade e existente em estado latente no Ser espiritual.

O direito dos homens, portanto, nem sempre é conforme a justiça. Só regula algumas relações sociais, enquanto na vida privada há uma infinidade de atos que são de competência exclusiva do tribunal da consciência. A justiça consiste no respeito aos direitos de cada um e, se o homem não souber onde termina o seu direito e onde começa o direito do outro, deve basear-se na regra áurea inscrita por Deus em seu coração e muito bem definida por Jesus: “Querei para os outros o que quereis para vós mesmos”.

Allan Kardec perguntou, aos Espíritos, qual a primeira assertiva de todos os direitos naturais do homem e a resposta foi "o de viver", porquanto a vida é necessária para o aperfeiçoamento dos seres. Todos possuem o instinto de conservação, qualquer que seja o seu grau de inteligência, e ninguém tem o direito de atentar contra a vida de seu semelhante ou fazer qualquer coisa que possa comprometer a sua vida corpórea.

Do seu direito natural de viver, decorre o de possuir, porque a propriedade, por exemplo, é um fruto que nasce de um outro direito, tão sagrado quanto o de viver, o de trabalhar. Aquilo que o homem consegue de um trabalho honesto, sem ter causado prejuízo moral ou material a outros, e que não resulta de danos para ninguém, é propriedade

e teve nada menos do que três sonhos que considerou bastante significativos. O mais curioso é que esses sonhos já lhe haviam sido preditos pelo Demônio, que à maneira do que se verificava com Sócrates, o advertia de coisas por acontecer. Descartes sentiu-se de tal maneira empolgado pelos sonhos que acreditou haver sido inspirado pelo Espírito da Verdade. O Abade Baillet registra esse fato em sua biografia do filósofo. Descartes se considerou capaz de pulverizar a velha e falsa ciência escolástica que lhe haviam impingido desde criança. (cumpre salientar que os sonhos demonstravam fazer ele parte de uma grande obra sobre a verdade dos fundamentos de uma Ciência admirável). E assim, pediu a Deus que o amparasse, que lhe desse força para realizar a tarefa que lhe cabia na grande obra a ser desenvolvida, vista nos sonhos. Rogou a Deus que o confirmasse no propósito de elaborar um método seguro para a boa direção do Espírito humano. E desse episódio, originou-se toda a sua obra que, por sua vez, abriu os caminhos da Ciência moderna. Nessa ocasião, ele não tinha mais do que 23 anos. Ele mesmo julgou-se demasiado jovem para tão grande e perigosa empreitada. Não-obstante, como um verdadeiro vidente, empenhou, dali por diante, todos os seus esforços no sentido de adquirir conhecimentos e condições para o trabalho entrevisto. E dezoito anos depois lançou o Discurso do Método, que rasgaria os novos caminhos da Ciência. Cauteloso, diante dos perigos que ameaçavam os pensadores livres da época, Descartes não deixou, entretanto, de cumprir o seu trabalho, que Espinosa prosseguiria mais tarde e que, ainda, se completaria com a dedicação de Allan Kardec. A epopéia do "cogito", realizada no silêncio da meditação, é uma indicação de rumos à nova Ciência. Descartes mergulhou em si mesmo, negando toda a realidade material, inclusive a do próprio corpo, na procura de alguma realidade positiva, que se afirmasse por si mesma, de maneira indubitável. Foi então que descobriu a realidade inegável do Espírito, proclamando, no limiar da Nova Era: "Cógito ergo sum", ou seja: "Penso, logo existo". E no mesmo instante em que reconheceu essa verdade, julgou-se isolado do Universo, perdido em si mesmo. Só podia afirmar a sua própria existência. Nada mais sabia... nem podia saber! 
legítima, que ele tem o direito de defender. Deus no Decálogo, disse: "Não roubarás”, e Jesus no Evangelho, confirmou, mandando dar a "César o que é de César".

Para o homem existe o conceito de legalidade de aquisição, conforme define sua lei, mas o homem de bem deve saber que nem tudo o que é legitimamente adquirido ou consagrado pela legislação humana está conforme a justiça natural. O que num século parece perfeito, no século seguinte se apresenta como bárbaro.

A verdadeira propriedade é aquela que se leva deste mundo, isto é, aquilo que é de uso da alma, a saber: a inteligência, os conhecimentos adquiridos, o Bem, realizado ao próximo, as qualidades morais, a consciência tranqüila, pois são bens "que as traças não roem nem o ladrão rouba", instrução de O Evangelho Segundo o Espiritismo.

Assim, vemos no Direito Natural Espírita princípios de justiça que exigem melhor compreensão e, por conseqüência, uma educação gradativamente aprimorada, mais abrangente e profunda a respeito de nossa maneira de ser, para que nossas ações $a$ posteriori sejam equilibradas e conscienciosas, refletindo-se no bem-estar de todos. Por isso é que sempre devemos estar em estado de vigília.

\subsection{O Direito Justo}

Justo vem do latim, justu, que normalmente traduzimos como conforme à justiça, à eqüidade ou à razão. O justo natural diz respeito ao homem e aos animais, quando tomado em consideração absoluta, mas apenas ao homem, quando existe um relacionamento do ato mesclado às suas conseqüências, mérito da faculdade racional humana, capaz de estabelecer relacionamentos do tipo causa-efeito.

$\mathrm{Na}$ Grécia como, também, em Roma - atingindo a Europa em geral -, até o início dos tempos modernos, o Direito não é tratado como coisa, mas como predicado, o que, vale dizer, como Justiça ou qualidade dos entes justos. E conclui-se que se pode afirmar que o modo de ser justo é próprio da arte jurídica.

Assimilamos, também, que a Justiça e o Direito se inter-relacionam, sendo que o Direito é apto a estabelecer o poderio de maneira plena à Justiça. E em premissa final: não são linguagens comuns, são linguagens diferentes.

Inserido o Justo Natural, chega-se à conclusão de que o Justo Natural não pode, por sua vez, estar contido no Direito. É difícil e complicado, de imediato, mas lembremos que o Direito não é a Justiça e sim a busca da virtuosidade da moral e da verdade ou, ainda, do que é comprovado, de forma dedutiva, ou seja, do método dedutivo 
da experiência jurídica do homem, devidamente capacitado pela prática da vida jurídica para essa avaliação.

A Justiça tem a função de dar a cada um o que lhe pertence. O Justo é o que é conforme a Justiça, subdividindo-se em vários âmbitos de sua natureza como, por exemplo, o Justo político, o Justo natural, o Justo particular, o Justo distributivo, o Justo corretivo, o Justo conjugal, o Justo doméstico, o Justo paternal etc.

$\mathrm{O}$ inesquecível professor emérito desta Academia de Direito, Miguel Reale, nos ensinava que "o Direito Natural oferece, ao mesmo tempo, os elementos lógico e axiológico que encontramos em todas as experiências jurídicas, ou História do Direito. A estrutura transcendental do Espírito humano oferece não-só a forma, ou categoria, própria do Direito como, também, em contato com a experiência da vida, pois fornece os conteúdos, os valores, fundamentais ou básicos, que constituem o Direito Justo".

E como isso é possível?

É que a prática da vida jurídica, comandada pelas categorias e valores próprios do Direito, vai fazendo com que os homens tomem consciência de que, na realidade da vida, existem não-só formas, mas sobretudo valores jurídicos, ou seja, bens, ou coisas boas, sem as quais não haveria sequer o Direito e a Justiça: a dignidade da pessoa humana, os direitos do homem, a sociedade, a comunidade das nações etc.

A famosa frase de Jesus Cristo no Templo dos Vendilhões "Dai a César o que é de César", demonstra firmemente a essência do Justo. Como nos ensina o professor doutor José Fleuri Queiroz em Código de Direito Natural Espírita:

No fundo, o jurídico é uma experiência, feliz ou malograda, de justiça e, mesmo quando de bom êxito, tem sempre caráter provisório, tão infinita é a esperança de justiça que nos anima e nos impele através do tempo. Por ser perene atualização do Justo, o Direito é condição primeira de toda a cultura, e nisso reside a dignidade da Jurisprudência.

O art. 300 do Código de Direito Natural Espírita, de autoria do professor Fleuri Queiroz (idem, às páginas 717), reza que:

"Aquele que, fazendo conscientemente o bem e reconhecendo que o faz, não pode ser responsabilizado por reconhecer que triunfou das más tendências e por estar satisfeito por isso, desde que não se envaideça, com o que cairia em outra falta. Desde que pode ter consciência do mal que fizer, deve tê-la igualmente do bem, a fim de saber se age bem ou mal. É pesando todas as suas ações na balança da lei de Deus, e sobretudo na da lei da justiça, do amor e da caridade, que 
ele poderá dizer a si mesmo se as suas ações são boas ou más e aprová-las ou desaprová-las".

O que é o Justo. Pela Teoria de Causa e Efeito e pela Teoria Reencarnacionista todo saldo devedor de nossas ações tem de ser cumprido nos mínimos detalhes da existência de todo Espírito encarnado.

Há uma famosa parábola, ensinada nos cursos da FEESP, que sempre cito aos meus alunos:

\begin{abstract}
um senhor-de-engenho, de benevolência ímpar, que dividia por igual lucros aos senhores agregados de uma aldeia, adquiriu inédita máquina elétrica ao engenho, substituindo os animais-de-tração. Aliás, o motivo maior, uma vez compadecer dos longos círculos a percorrer, horas e horas, pelos eqüinos auxiliares, torturados em épocas de calor. Justamente na inauguração da máquina elétrica, o senhorde-engenho, ao manuseá-la, perde um dos dedos de uma das mãos. Inconformados, o contingente de homens e mulheres corre para um médium da aldeia a perguntar o porquê de ele passar por tal situação. O senhor, sensitivo e espírita, refuta que o correto e o justo seria o senhor-de-engenho ter perdido um braço, dada a situação em outra encarnação na qual ele agredira um outro senhor, arrancando-lhe com foice um de seus braços. E acrescenta que pela sua bondade, nessa encarnação atual, gradativa e voltada para o Bem, o Justo prevalecera, aumentando-lhe pedaço por pedaço da carne, com um saldo de somente atingir um dedo; todavia, a punição teria de se suceder e que era por esse motivo que passara pelo desconforto.
\end{abstract}

Trata-se de um juízo corretivo nas transações entre os indivíduos, isto é, uma justiça distributiva apta a produzir a reparação nas relações anteriores; e esta reparação afirmada, está a presidir a igualdade nas trocas e demais relações bilaterais e anteriores. Sabe-se lá, no âmbito do Plano Maior, o que o senhor-de-engenho havia realizado nas encarnações anteriores àquela vivida, como parâmetro, entre os senhores agregados daquela aldeia!

Esta fábula acima vem ao encontro das leituras de Tomás Antonio Gonzaga em seu Tratado quanto à oposição dele a qualquer concepção naturalista por meio da aceitação de um princípio superior de ordem divina, concebido como o princípio e o elemento dinâmico de toda e qualquer ordem observável na realidade, e dotado de uma vontade totalmente livre e capaz de conduzir os acontecimentos em qualquer sentido. Toda as indicações de uma ordem natural preexistente ou coexistente são afastadas por impossíveis e inconcebíveis motivos. A própria concepção de natureza é ligada em direta 
subordinação a essa Ordem Divina - isto é, não apresenta um estágio de vida humana -; todavia, uma fase de evolução moral iniciada pela desobediência aos primeiros preceitos do Criador de Todas-as-Coisas.

Portanto, a justiça distributiva é igualdade de caráter proporcional, uma vez estabelecida em consonância com critérios de estimação e avaliação dos Espíritos analisados. E este critério é o mérito de cada qual que os diferencia pela sua própria evolução, tornando-os mais ou menos merecedores de tais ou quais benefícios ou ônus sociais, como nos ensina o professor associado desta Academia de Direito da Universidade de São Paulo, Eduardo Carlos Bianca Bittar, em seu livro intitulado A Justiça em Aristóteles.

São regras que têm de ser observadas, porque são produzidas artificialmente por uma "razão raciocinante", seja por convenção de particulares, seja pelo príncipe como mandatário do corpo social, sendo o resultado do contrato social, onde as regras jurídicas são as contratuais. No Espiritismo, ao contrário do que imaginamos, tudo é estabelecido - mediante a Teoria Reencarnacionista ou pela Pluralidade das Existências - em consonância com as condições da vontade de evolução de cada um de nós; todavia, as regras a serem cumpridas têm caráter obrigatório, voltadas ao perfil do Justo (individual, social, econômico etc).

A professora doutora, desta Academia de Direito, Jeannette Antonios Maman assevera com muita propriedade em seu livro intitulado Fenomenologia Existencial do Direito que:

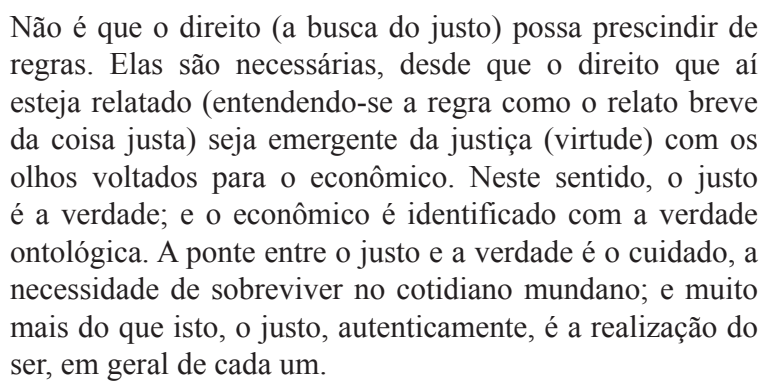

Os hadiths, ou ditos, que junto ao Qur'an fornecem a base da char'ia muçulmana, formam a coletânea tradicional de ensinamentos do querido Profeta Mohammed como, também, de seus companheiros. Justo está incluso na Sura da Manhã, como assevera Karen Amstrong em livro intitulado Maomé uma biografia do Profeta:

"A Sura da Manhã dera-lhe uma ordem de natureza claramente social: homens e mulheres devem cuidar dos membros favorecidos da tribo. Isso fora crucial 
para o antigo ideal da muruwah (unidade), mas os koreichitas (nome da tribo de Mohammed) pareciam tê-lo perdido de vista. O Qur'an diz que essa mensagem fora de suma importância nas revelações de todos os profetas anteriores".

E Odir Züge Junior complementa em Judaismo e Islamismo ... (referência no final desta pesquisa):

"Se foi dito por todos os profetas, é a vontade do divino que assim seja. Não é de ser que uma fé tão simples e ao mesmo tempo capaz de falar diretamente ao coração das pessoas, tenha se espalhado tão rapidamente. O que pede o Qur'an é algo que todos acabam por entender como Justo".

Há um final profundo na narrativa de Züge Junior:

"Sociedades mais justas são menos violentas".

De volta à reencarnação, os Espíritos permanecem na erraticidade, após o desencarne, no Universo Maior, aonde aprendem, e apreendem, por longos períodos, tudo o que tem de cumprir para a sua evolução, numa combinação do binômio conhecimento/ liberdade, adquiridos na pluralidade da existência terrena. São graus evolutivos, desde a existência em mundos primitivos até a permanência em mundos de prova e expiação, do nosso conhecimento, como o planeta Terra. E nesta escala evolutiva têm de passar pelos mínimos e múltiplos detalhes para equacionar saldos, débitos e créditos, já que a Justiça Divina é voltada ao perfeccionismo e rígida ordem hierárquica espiritual, comandada, geralmente, por Espíritos de Luz. Eles são os intermediários e nossos interlocutores, principalmente entre mundos de estágio e os de nível superior, como os mundos felizes, celestiais, aonde se encontram grandes mestres da História Espiritual da Humanidade.

Todavia, mediante o Justo, existem fases que trazem o sofrimento como ponte essencial da evolução, sendo categoricamente desprezadas pela maioria dos Espíritos em sua trajetória terrena. Veja-se os exemplos de Judas Iscariotes que, arrependido pelo ato praticado - jogando em terra as moedas de prêmio pela entrega de Jesus Cristo aos centuriões romanos, por meio do beijo -, teve de passar por encarnações de vivência extrema.

Seguindo instruções dos cursos mediúnicos, a seguir alguns ítens de supostas reencarnações, válidas somente aos estudiosos do Espiritismo, a saber: Joana D’Arc é a reencarnação de Judas Iscariotes, uma das heroínas da história política da França, que todos conhecem o seu final na existência terrena: queimada em fogueira (punição medieval).

Do centurião romano Cassius Caio Longinus que, para se cientificar da saída do corpo carnal do Mestre Jesus, transpassou o Salvador com a ponta da sua espada. Da espada, composta por uma lança - futuramente a lança sagrada que permaneceu nas 
mãos do imperador Constantino, do Rei Carlos Magno, da Família dos Habsburgo e do führer Adolf Hitler -, rompem-se tecidos do coração do Cristo e desta ponta são jorrados água (o batismo) e sangue (a purificação). Longinus que tinha precária visão, torna-se imediatamente portador de excelente visibilidade óptica. Ele é reencarnado Dom Pedro II, um dos benfeitores da progressividade da cultura brasileira, quando príncipe-regente da Família Real portuguesa no Brasil (missão espiritual).

Ou, ainda, Lucano (apelidado São Lucas), médico do corpo e da alma, reencarnado Adolfo Bezerra de Menezes Cavalcanti, novamente médico, nascido no Ceará e radicado no Rio de Janeiro, aonde tratava, gratuitamente, pobres locais de doenças contagiosas. Ele é o patrono da Federação Espírita Brasileira (missão espiritual).

Enfim, Espíritos seculares que vêm trabalhando em prol da Humanidade, como Rabi Isaac Luria, estudioso brilhante do século XVI, que aos 13 anos de idade era chamado de Ari, significado de "o Leão Sagrado". Ele tinha o dom de explorar as profundezas internas do Zohar, sondando os seus mistérios. As palavras poéticas e os segredos extraordinários do Zohar foram decifrados por ele, revelando-nos, por último, um código notável, explicando a forma de como a Energia Espiritual age neste mundo físico. O seu maior legado foi a composição cabalística Os Escritos de Ari, que gerou a conhecida Cabala Luriânica. (missão instrutiva)

É claro que são Espíritos que se tornaram inesquecíveis aos olhos da Justiça, do Conhecimento e da Conduta dos homens e mesmo aos do Criador de Todas-as-Coisas, o Legislador das Leis Naturais. ${ }^{13}$

\footnotetext{
${ }^{13}$ Nessa classificação de legião de Espíritos encontram-se os profetas. As predições do futuro sempre foram feitas pelos profetas, os oráculos que prevêem de maneira sui generis (dormindo, por exemplo) o porvir. O maior profeta do século XX foi Edgard Cayce, nascido em Kentucky, EUA, por meio de seus poderes proféticos ao lado do seu colega francês, Nostradamus. Em transe, Cayce realizava leituras do futuro e do passado. Era portador de uma vidência que preveu o período da Grande Depressão, da deflagração da Segunda Guerra Mundial ou a criação de movimentos dos direitos civis almejada pelas gangues norte-americanas. Nos anos 20, quando a Europa se recuperava da Primeira Guerra Mundial, os EUA progrediam e nomes famosos corriam a Cayce em busca de sucesso. Seus clientes enriqueciam e nessa corrida Thomas Edison, que obteve do vidente riquíssimas leituras sobre a eletricidade como, também, aqueles que investiam em ações da Bolsa norte-americana. Edgard Cayce não era conhecedor de Medicina, Farmácia, Economia: tudo a ele era revelado por meio de sonhos que, em transe, transmitia aos ouvintes. Era fotógrafo. Cayce atuou em áreas como Geologia ou Física, prevendo a localização da Atlântida nas Bahamas, citando documentos sobre a Cidade Perdida, existente há 10 mil anos atrás, a serem resgatados pelos arqueólogos; dentre eles, alguns encontradiços na pata esquerda da Esfinge, no Egito. Não há autorização e nem solicitação ao Governo egípcio para essa busca em escavações do famoso templo. Nos mesmos moldes, isto é, em transe, descreveu a vida dos homens, mulheres e crianças da tribo dos essênios visitada por Jesus Cristo e, ressalta-se, tudo antes da descoberta dos Pergaminhos do Mar Morto, nos anos 50. Como, também, a alteração fluídica das águas do Rio Nilo há milhares de anos atrás, comprovada pelos arqueólogos e geólogos nos anos 50 . A história do petróleo, os conflitos mundiais foram previstos há anos por Cayce. Os Hopi (índios dos EUA) e os Maias chegaram a prever para o século XXI o grande Dia da Purificação, por meio da inclinação do eixo da Terra, o que acarretará significativas mudanças do planeta ... e Edgard Cayce compartilhou em seus sonhos igual
} 
Nesse redemoinho, percebe-se a presença da Justiça Divina, por meio do Justo, que é completado, inteiramente, pela vontade de cada um de nós. Todos nós, que concordamos e traçamos em minúcias a composição das linhas d'O Livro da Vida. O Livro da Vida é o conteúdo de tudo que decidimos cumprir, no Plano Maior, na trajetória terrena, ou em cada dia de existência no seio da Humanidade, em estado de vigília e provedor da manutenção da Lei do Amor, a maior de todas as leis do Universo. O Livro é tão pessoal e individual (a individualidade), que temos o direito ou privilégio ao livre arbítrio para compor nossas feições (fenótipos e genótipos) retirados do Ectoplasma, um dos mais elementares e importantes componentes encontrados nas galáxias do Universo pós-Big Ben; esta é a denominação científica da explosão que deu origem à Criação do Universo.

Enfim, todos, ao nascer, sabemos que um dia teremos de partir (idéias inatas auxiliam) para um Mundo de Luz; o que prevalece é o legado a deixar e esse é o mérito do Espírito durante a existência terrena. Os Espíritos são avaliados pela evolução adquirida, pelo discernimento correto do Bem e do Mal.

O Espiritismo, provando de maneira patente a existência de um mundo invisível, leva, forçosamente, a uma ordem de idéias bem diversa, uma vez que dilata o horizonte moral limitado à Terra. A importância da vida corporal diminui na medida em que a vida espiritual cresce e, assim, nós nos colocamos naturalmente em outro ponto de vista, e o que nos parecia uma montanha gigante não nos afigura maior do que um grãode-areia.

As vaidades, as ambições, neste planeta, tornam-se puerilidades, como brinquedos infantis, em presença do futuro grandioso que nos espera. Atendo-nos menos às coisas terrenas, tendemos, igualmente, a nos satisfazer menos às expensas dos outros, de onde uma diminuição no sentimento do egoísmo.

O Espiritismo não se limita a provar o mundo invisível. Mediante os exemplos que fazem desenrolar aos nossos olhos e percepção humana, o Espiritismo nôlo revela em sua realidade e não de maneira como a imaginação o havia feito conceber. Ele nô-lo mostra povoado de seres felizes ou infelizes, porém prova que a Caridade, a soberana Lei de Cristo, pode aí assegurar a paz e a alegria. Por outro lado, assistimos ao espetáculo da sociedade terrena que se auto-estraçalha sob o império do egoísmo e que, entretanto, viveria feliz e pacífica sob o da Caridade.

parâmetro. A vantagem de parte da história do maior profeta do século XX se deve à sua secretária e taquígrafa Gladys Davis, a quem a Humanidade agradece, porque Edgard Cayce nos ajudou a saber com precisão quem somos e por quê estamos aqui, neste planeta. 
Com a Caridade, tudo é benefício para o homem. Com o Espiritismo, o homem compreende que tem tudo a ganhar, realizando o Bem e tudo a perder, optando pelo Mal. Ora, entre a certeza de perder ou a de ganhar, a escolha não pode ser duvidosa. E é por esse motivo a propagação de que a idéia espírita tende, necessariamente, a tornar os homens melhores em suas mútuas relações. O que ele faz hoje, relativamente aos indivíduos, fará amanhã em relação às massas, quando estiver difundido de maneira geral e mais proveitosa.

O Espiritismo não pretende nada; apenas nos ensina que, por meio dele, apreende-se o dever de praticar a justiça com compreensão e razão. E assim, Espíritos encarnados são transformados, pela educação espiritual ou mediúnica, portadores legítimos de estar em condições de agir de maneira a ser Justo, como próprio da arte jurídica.

\section{Conclusão}

O Espiritismo é uma doutrina filosófica moderna, perfeitamente estruturada por um pensador, escritor e pedagogo; homem de letras e ciências, afamado por sua cultura e trabalhos científicos e que assinou obras espíritas com o pseudônimo de Allan Kardec.

O Espiritismo é uma doutrina complexa, que abrange todo o campo do conhecimento e se apresenta enquadrada na seqüência epistemológica da:

a. Ciência, como pesquisa dos chamados fenômenos paranormais, dotada de métodos próprios, específicos e adequados ao objeto que investiga, tendo dado origem a todas as ciências do paranormal, até à Parapsicologia atual e seu ramo romeno, que se disfarça sob o nome pouco conhecido de Psicotrônica, para não assustar os materialistas opostos à doutrina;

b. Filosofia, como interpretação da natureza dos fenômenos e reformulação da concepção do mundo e de toda a realidade, segundo as novas descobertas científicas; aceita oficialmente no plano filosófico como consta do Dicionário Filosófico do Instituto de França; no País, é reconhecida pelo Instituto Brasileiro de Filosofia, constando do volume Panorama da Filosofia em São Paulo, edição conjunta do Instituto e da Universidade de São Paulo, com coordenação do professor titular Luiz Washington Vitta;

c. Religião, como conseqüência das conclusões filosóficas, baseadas nas provas da sobrevivência humana após a morte e nas ligações históricas 
e genéricas do Cristianismo com o Espiritismo: considerado como a Religião em Espírito e Verdade, anunciadas por Cristo, segundo os Evangelhos; religião espiritual, sem aparatos formais, dogmas de fé ou instituição igrejeira, sem sacramentos;

d. Gnosiologia, porque essa seqüência anterior obedece às leis da Gnosiologia, pelas quais o conhecimento começa nas experiências do homem com o mundo e se desenvolve nas ilações do pensamento humano, dentro do quadro da realidade conhecida; como no Espiritismo essa realidade supera os limites da vida física, a moral se projeta no plano das relações do homem com a Divindade, adquirindo sentido religioso.

Allan Kardec em $A$ Viagem Espírita enumera itens importantes com relação ao Espiritismo no epílogo do livro citado, a saber:

a. O Espiritismo agrada, porque satisfaz à aspiração instrutiva do homem em relação ao futuro; b. porque apresenta o futuro sob um aspecto que a razão pode admitir; c. porque a certeza da vida futura faz com que o homem enfrente com paciência as misérias da vida presente; d. porque, com a doutrina da pluralidade das existências, essas misérias revelam uma razão de ser, tornam-se explicáveis e ao invés de serem atribuídas à Providência, em forma de acusação, passam a ser justificáveis, compreensíveis e aceitas sem revolta; e. porque é um motivo de felicidade saber que os seres que amamos não estão perdidos para sempre que os encontraremos, além de estarem constantemente conosco [inclusive Espíritos inferiores, os animais de estimação, que tanto amamos e estiveram habitando conosco neste planeta]; f. porque as orientações dadas pelos Espíritos são de molde a tornar os homens melhores em suas relações recíprocas; estes e, além destes, outros motivos que só os Espíritos podem compreender. Em contrapartida, que sedução oferece o materialismo? O nada! Nele, todo o consolo que apresenta para as misérias da vida! Com tais elementos, o futuro do Espiritismo não pode ser duvidoso e, todavia, se devemos nos surpreender com alguma coisa, será com o fato de que tenha franqueado um caminho tão rápido, por meio dos preconceitos.

Juridicamente, o Espiritismo tem sido auxiliar e parceiro como um dos mais importantes meios comprobatórios de crimes, envolvendo rastreamentos investigativos de homicídio, a exemplo do Direito norte-americano, quando juízes dos tribunais dos 
EUA se servem de sensitivos que têm essas mediunidades; inclusive, uma das mais eficientes instituições do mundo, a Interpol. Tanto juristas quanto investigadores têm acatado orientações prestadas por eles em casos de homicídios. São serviços vinculados ao Espiritismo que têm resultados satisfatórios e alta precisão, como data, local e relatos judiciais; alguns, inimagináveis na trilha da investigação pela própria Polícia que, grata, possui robustas provas, solucionando detalhes de processos complexos, muitos inconclusíveis, antes da interferência do Espiritismo. Saliento, todavia, que os EUA utilizam a nomenclatura Paranormalidade que, na verdade, tem o mesmo significado anterior.

A Associação Brasileira de Magistrados Espíritas (Abrame) composta por mais de 700 juízes, desembargadores e ministros de Tribunais Superiores, aceitando apenas togados como membros, deu margem à criação da recém-fundada Associação Jurídica Espírita (AJE), de São Paulo. Tanto a Abrame quanto a AJE defendem, entre outros tópicos, o uso de carta psicografada nos tribunais.

O meritíssimo juiz federal Zalmino Zimmermann, presidente da Abrame, em reportagem ao jornal Folha de S. Paulo, diz com propriedade que "o propósito da associação é questionar os poderes constituidos para que o Direito e a Justiça sofram, mais de perto, a influência de espiritualizar. O objetivo geral é a espiritualização e a humanização do Direito e da Justiça".

Saliento que a AJE tem ramificação, também, nos Estados do Espírito Santo, Rio de Janeiro e Rio Grande do Sul

Mediante todo o quadro exposto, a complexidade do Espiritismo tornase facilmente compreensível, porque tudo no Universo se processa com relação a ação e o controle de Leis Naturais, as quais, por sua vez, correspondem à imanência do Pai Todo-Poderoso no Mundo por meio de suas leis. E assim, toda a realidade verificável é absolutamente natural, de maneira que os Espíritos e suas manifestações não são sobrenaturais; todavia, fatos naturais e absolutamente explicáveis, resultantes de leis que a pesquisa científica esclarece. O sobrenatural só se refere a Deus, cuja natureza não é acessível ao homem neste estágio de sua evolução, mas o será, possivelmente, quando este atingir a graduação evolutiva. Todas as possibilidades estão abertas e franqueadas ao homem em todo o Universo, desde que ele avance no desenvolvimento de suas potencialidades espirituais, segundo as leis da transcendência.

É notável que façamos desaparecer a idéia de antagonismo entre Espiritismo e Ciência. A verdadeira Ciência não hostiliza o Espiritismo, ela não é sectária e não se manifesta ao sabor das opiniões pessoais. Por sua vez, o Espiritismo não pode vir contra 
a Ciência, porque nela se busca as bases objetivas de sua Doutrina e, de acordo com ela, estabelecido é as novas explicações de fatos psíquicos.

No final de O Livro dos Espíritos, sob o título “Conclusão", Allan Kardec faz um resumo do conteúdo da obra como, também, das repercussões da mesma na sociedade da época. E em um dos trechos de n. 320.2 extraio:

o Espiritismo, portanto, repousa menos no maravilhoso e no sobrenatural do que a própria religião. Os que o atacam nesse sentido não o conhecem. E, mesmo que fossem os maiores sábios, nós lhe diríamos: 'se a vossa Ciência, que vos ensinou tantas coisas, não vos revelou que o domínio da Natureza é infinito, sois apenas meio-sábios'.

São Paulo, setembro de 2007.

\section{Referências}

ALMEIDA JÚNIOR, A. O Espiritismo é uma religião? Revista da Faculdade de Direito da Universidade de São Paulo, São Paulo, v. 34, n. 3, p. 311-317, set./dez. 1938.

ANDRADE, Hernani Guimarães. Espírito, perispírito e alma. São Paulo: Ed. Pensamento, 1984.

ARMSTRONG, Karen. Maomé, uma biografia do profeta. Tradução de Andréia Guerini, Fabiano Seixas Fernandes e Walter Carlos Costa. São Paulo: Cia das Letras, 2002.

ARRAIA, Eduardo. Espiritismo. São Paulo: Editora Ática, 1996.

BITTAR, Eduardo Carlos Bianca. Direito e justiça em São Tomás de Aquino. Revista da Faculdade de Direito da Universidade de São Paulo, São Paulo, v. 93, 1998.

. Direito natural: sentido natural versus sentido cultural. Revista de Informação Legislativa, v. 38, n. 152 , p. 2001.

. Evolução Histórica da Filosofia. Revista da Faculdade de Direito da Universidade de São Paulo, São Paulo, v. 89, 1994.

. A justiça em Aristóteles. São Paulo: Ed. Forense Universitária, São Paulo, 1999.

BLAVATSKY, Helena. Sinais dos Tempos. In: A DOUTRINA Oculta. São Paulo: Editora Hemus, 1977.

BOZZANO, Ernesto. Popoli primitivi e manifestazioni supernormali. Verona: Edizioni Europa, Verona, Itália, 1955. 
CAMPBELL, Joseph. As máscaras de Deus: mitologia oriental. São Paulo: Editora Palas Athena, 1994.

CIAMPONI, Durval. A evolução do princípio inteligente. São Paulo: Ed. FEESP, 1995.

COSTA, Maria das Graças S. Albegaria. O direito natural e o seu histórico. Revista de Julgados do Tribunal de Alçada do Estado de Minas Gerais, Belo Horizonte, n. 13, 1987.

DENIS, Léon. Aprés de la mort. Paris: Librairie des Sciences Psychiques, 1944.

DOYle CONAN, A. A História do espiritismo. Tradução de Júlio Abreu Filho. São Paulo: Ed. O Pensamento, 1960.

FEDERAÇÃO ESPÍRITA DO ESTADO DE SÃO PAULO. Curso básico de espiritismo. São Paulo: FEESP, 1993. v. 1 e 2.

. Noções de história da filosofia: curso de introdução ao conhecimento do espiritismo. São Paulo: FEESP, 1993.

FERREIRA, Aurélio Buarque de Holanda. Novo dicionário da língua portuguesa. Rio de Janeiro: Editora Nova Fronteira, 1986.

GALVÃO, Vinícius Queiroz. A Associação quer espiritualizar o Judiciário. Folha de S.Paulo, Caderno Cotidiano, 19/05/2008.

GONZAGA, Tomás Antonio. Tratado de Direito Natural. São Paulo: Martins Fontes, 2004.

GOSWANI, Amit. A janela visionária: um guia para a iluminação por um físico quântico. São Paulo: Ed. Cultrix, 2005.

GROTIUS, Hugo. De jure belli ac Pacio Libre Tres. Traduzido por Francis W. Kelsey. Oxford: Claredon Press, 1925.

KARDEC, Allan. O céu e o inferno. São Paulo: Federação Espírita do Estado de São Paulo, 1992. . O Evangelho segundo o espiritismo. São Paulo: Federação Espírita do Estado de São Paulo, 1992.

. A Gênese. São Paulo: Federação Espírita do Estado de São Paulo, 1992.

. O livro dos espíritas. São Paulo: Federação do Estado de São Paulo, 1992.

. O livro dos médiuns. São Paulo: Federação Espírita do Estado de São Paulo, 1992.

. O que é o espiritismo. São Paulo: Federação Espírita do Estado de São Paulo, 1994. 
. Viagem Espírita em 1862. São Paulo: Federação Espírita do Estado de São Paulo, 1993.

KLOPPEMBURG, Frei Boaventura. O espiritismo no Brasil. Rio de Janeiro: Editora Vozes, 1960.

LANTIER, Jacques. O espiritismo. Lisboa: Edições Lisboenses 70, 1980.

LEX, Ary. Pureza doutrinária. 3. ed. São Paulo: FEESP, 1996.

MACEDO, Lourival Gomes. Tomás Antonio Gonzaga. São Paulo: EDUSP, 2002.

MACHADO, Ubiratan. Os intelectuais e o espiritismo. Rio de Janeiro: Editora Antares/INL, 1983.

MAMAN, Jeannette Antonios. Fenomenologia existencial do direito: crítica do pensamento jurídico brasileiro. 2. ed. São Paulo: Ed. Quartier Latin do Brasil, 2003.

MARTINS, Ives Gandra da Silva. Fundamentos do direito natural à vida. São Paulo: Revista dos Tribunais, 1987.

MASCARO, Alysson Leandro. Os dias de nossas vidas. Catanduva: Ed. Alma, 1998.

. Introdução ao estudo do espiritismo. Catanduva: Ed. Alma, 1999.

MIRANDA, Hermínio C. Deolindo Amorim. O Espiritismo e os problemas humanos. São Paulo: USE, 1985

PIRES, José Herculano. A ciência admirável. São Paulo: Editora Cultural Espírita Edicel Ltda., 1995.

. O espírito e o tempo: introdução antropológica ao espiritismo. Sobradinho-DF: Editora Cultural Espírita Edicel Ltda, 1995.

. Os filósofos. Editora Cultrix Ltda., São Paulo, 1996.

. Introdução à filosofia espírita. Editora Paidéia Ltda. São Paulo, 1997.

. O ser e a serenidade. São Paulo: Coleção Filosófica Edicel, 1997.

PEDROSO, Antonio Carlos de Campos. Concepção neotomista do direito natural. Revista da Faculdade de Direito da Universidade de São Paulo, São Paulo, v. 84/85, p. 12-30, 1989/1990.

PRADO JUNIOR, Caio. Dialética do conhecimento. São Paulo: Editora Brasiliense, 1997.

QUEIROZ, José Fleuri. A educação como direito e dever. À luz da filosofia e do direito natural. São Paulo: Editora e Distribuidora de Livros Mundojurídico Ltda., 2003. 
. Filosofia do direito. A justiça pura e completa. Código de Direito Natural Espírita. Código Fleuri. Projeto comentado. São Paulo: Editora e Distribuidora de Livros Mundojurídico Ltda., 2006.

REALE, Miguel. Filosofia do direito. 17. ed. São Paulo: Editora Saraiva, 1996.

RUSSEL, Bertrand. Misticismo e Lógica. Rio de Janeiro: Zahar Editores, 1997.

SÃO MARCOS, Manoel Pelicas. Filosofia espirita e seus temas. São Paulo: Liv. e Ed. Espírita Humberto de Campos, FEESP, 1993.

SERTILlANGES, H. D. La philosophie de S. Tomas. Paris: Ed. Montchréstien, 1940.

STOLL, Sandra Jacqueline. Espiritismo à brasileira. São Paulo: EDUSP, 2003.

TELlES JUNIOR, Goffredo da Silva. Filosofia do direito. São Paulo: Ed. Max Limonad, 1966. tomo II.

VILLEY, Michel. Des delits et des peines dans la philosophie du droit naturel classique. Archives de Philosophie du Droit, Paris, n. 28, 1983.

. La formation de la pensée juridique moderne. Paris: Ed. Montchréstien, 1968.

ZÜGE JUNIOR, Odir. Judaísmo e Islamismo: a injunção das tradições religiosas com a prática não-jurídica. Orientação da Professora Doutora Jeannette Antonios Maman, do Departamento de Filosofia e Teoria Geral do Direito da FDUSP. Biblioteca Central da Faculdade de Direito da Univeridade de São Paulo, São Paulo, 2004. 